\title{
Nickel(II) N-benzyl-N-methyldithiocarbamato complexes as precursors for the preparation of graphite oxidation accelerators
}

\begin{tabular}{|r|l|}
\hline Journal: & Zeitschrift für Anorganische und Allgemeine Chemie \\
\hline Manuscript ID: & zaac.201000091.R1 \\
\hline Date - Manuscript type: & Article \\
\hline Complete List of Authors: & $\begin{array}{l}\text { Travnicek, Zdenek; Palacky University, Inorganic chemistry } \\
\text { department } \\
\text { Pastorek, Richard } \\
\text { Starha, Pavel } \\
\text { Popa, Igor } \\
\text { Slovak, Vaclav }\end{array}$ \\
\hline Keywords: & $\begin{array}{l}\text { Nickel(II)complex, Dithiocarbamato ligand, Crystal structure, } \\
\text { Graphite oxidation accelerator }\end{array}$ \\
\hline
\end{tabular}

\section{s) scholaroNE" \\ Manuscript Central}




\title{
ARTICLE
}

DOI: 10.1002/zaac.200

\section{Nickel(II) $N$-benzyl- $N$-methyldithiocarbamato complexes as precursors for the preparation of graphite oxidation accelerators}

\author{
Zdeněk Trávníček, ${ }^{*[a]}$ Richard Pastorek, ${ }^{[\mathrm{a}]}$ Pavel Štarha, ${ }^{[\mathrm{a}]}$ Igor Popa,${ }^{[\mathrm{a}]}$ and Václav Slovák ${ }^{[\mathrm{b}]}$
}

Keywords: Nickel(II)complex; Dithiocarbamato ligand; Crystal structure; Graphite oxidation accelerator.

\begin{abstract}
The molecular structures of $\mathbf{4}$ and $\mathbf{5} \cdot \mathrm{H}_{2} \mathrm{O}$ were determined by a single crystal X-ray analysis. In all cases, the $\mathrm{Ni}(\mathrm{II})$ atom is four-coordinated in a distorted square-planar arrangement with the $\mathrm{S}_{2} \mathrm{PX}$, and $\mathrm{S}_{2} \mathrm{P}_{2}$ donor set, respectively. The catalytic influence of selected complexes $\mathbf{1}, \mathbf{3}, \mathbf{5}$, and $\mathbf{6}$ on graphite oxidation was studied. The results clearly indicated that the presence of the products of thermal degradation processes of the mentioned complexes have impact on the course of graphite oxidation. A decrease in the oxidation start temperatures by about $60-100{ }^{\circ} \mathrm{C}$ was observed in the cases of all the tested complexes in comparison with pure graphite.
\end{abstract}

* Corresponding Author

Fax: +420585634 357

E-Mail: zdenek.travnicek@upol.cz

[a] Department of Inorganic Chemistry

Faculty of Science, Palacký University

Tř. 17. listopadu 12, CZ-771 46 Olomouc, Czech Republic

[b] Department of Chemistry

Faculty of Science, University of Ostrava

30. dubna 22, CZ-701 03 Ostrava, Czech Republic

Supporting information for this article is available on the

WWW under http://dx.doi.org/10.1002/zaac.201000xxx or from the author.

\section{Introduction}

Many compounds involving the dithiocarbamate (dtc) moiety were reported up to now in connection with their applications. These compounds have been found to be useful as fungicides [1] or accelerators of vulcanization [2]. However, the spectrum of potential use of these compounds may be also broadened on the field of in vitro anticancer activity as can be demonstrated by the following examples. The 4(3H)-quinazolinone derivatives with dithiocarbamate side chains, such as (3,4-dihydro-2-methyl-4-oxoquinazolin6-yl)-methyl-[4-(4-fluorophenyl)piperazine]-1-carbodithioate, showed promising in vitro anticancer activity $\left(\mathrm{IC}_{50}=0.5\right.$ $\mu \mathrm{M})$ against human myelogenous leukaemia cell line (K562) [3]. Another dithiocarbamate derivative, 4-methylsulfinyl-1(S-methyldithiocarbamyl)-butane (sulforamate), serves as a bearer of cancer chemopreventive effect [4]. The efficient protection of $N$-benzyl- $D$-glucamine-dithiocarbamate against cisplatin-induced nephrotoxicity (it is able to chelate platinum and thus to decrease the possibility of its reactions with sulphur-containing renal proteins or enzymes) has also been reported recently [5].
Several thousands of transition metal complexes involving the dithiocarbamate moiety have been prepared and reported to date and some of them are very promising from the biological activity point of view. The Pt(II) complex of the [Pt(esdt)(py)Cl] composition, where esdt = ethylsarcosinedithiocarbamate and py = pyridine, is highly cytotoxic against several human cancer cell lines, and moreover, this substance was not found as nephrotoxic, contrary to cisplatin [6]. $\left[\mathrm{Au}(\mathrm{dmdt}) \mathrm{X}_{2}\right]$ and $\left[\mathrm{Au}(\mathrm{esdt}) \mathrm{X}_{2}\right]$ are the representatives of non-platinum complex with the promising anticancer activity, which is even higher compared to cisplatin; $\mathrm{dmdt}=N, N^{\prime}-$ dimethyldithiocarbamate, $\mathrm{X}=\mathrm{Cl}$ or $\mathrm{Br}$ [7]. The antifungal activity, well-known for dithiocarbamate derivatives, was proved for tin(IV) complexes with pyrrolidinedithiocarbamate [8].

Nickel is known as a suitable transition metal for the preparation of complexes and it is not surprising that over three thousand compounds (SciFinder, 2010) and 163 X-ray structures (Crystallographic Structural Database, CSD, ver. 5.30, September 2009 update [9]) involving an $\mathrm{NiS}_{2} \mathrm{CN}$ motif have been reported to date. Among these compounds, the nickel(II) complexes involving the $\mathrm{NiPN}\left(\mathrm{S}_{2} \mathrm{CN}\right)$ or $\mathrm{NiP}_{2}\left(\mathrm{~S}_{2} \mathrm{CN}\right)$ moiety, such as [Ni(4-MePzdtc $\left.)\left(\mathrm{PPh}_{3}\right)(\mathrm{NCS})\right]$ [10], and [Ni(MeSdtc)(dppe)] [11], respectively, have been described in the literature; 4-MePzdtc $=4$-methylpiperazinedithicarbamate anion, $\mathrm{PPh}_{3}=$ triphenylphosphine, $\mathrm{MeSdtc}=$ $N$-methyl- $N$-sulfonyldithiocarbamate, dppe $=1,2$-bis (diphenylphosphine)ethane. However, no nickel complexes containing the $N$-benzyl- $N$-methyldithiocarbamate anion (BzMedtc) within the mentioned moieties, have been reported to date. 
The presented series of compounds follows a great number of nickel dithicarbamato complexes previously prepared at our department [see ref. 12,13 and the references cited therein]. In this paper, we deal with seven nickel(II) complexes, whose structures, according to the literature research, for the first time involves a combination of the BzMedtc and $\mathrm{PPh}_{3}$ ligands. The complexes $\left[\mathrm{Ni}(\mathrm{BzMedtc})\left(\mathrm{PPh}_{3}\right) \mathrm{X}\right]$ (1-4) were synthesized from $\left[\mathrm{Ni}(\text { BzMedtc })_{2}\right]$, using its reaction with $\left[\mathrm{NiX}_{2}\left(\mathrm{PPh}_{3}\right)_{2}\right]$, where X stands for $\mathrm{Cl}^{-}$(for the complex 1) $\mathrm{Br}^{-}(\mathbf{2}), \mathrm{I}^{-}(\mathbf{3})$ and $\mathrm{NCS}^{-}(\mathbf{4})$. The $\left[\mathrm{Ni}(\mathrm{BzMedtc})\left(\mathrm{PPh}_{3}\right)_{2}\right] \mathrm{Y}$ complexes $(\mathrm{Y}=$ $\mathrm{ClO}_{4}^{-}$for $\mathbf{5}, \mathrm{BPh}_{4}^{-}$for $\mathbf{6}$ and $\mathrm{PF}_{6}^{-}$for 7) were prepared by the reaction of complex $\mathbf{1}$ with the appropriate alkaline salt and triphenylphosphine (see Scheme 1). The products were characterized by various physical methods including ${ }^{31} \mathrm{P}\left\{{ }^{1} \mathrm{H}\right\}$-NMR spectroscopy. The X-ray structures of the representatives of both types of complexes, i.e. $\left[\mathrm{Ni}(\mathrm{BzMedtc})\left(\mathrm{PPh}_{3}\right)(\mathrm{NCS})\right]$ (4) and $[\mathrm{Ni}$ (BzMedtc)$\left.\left(\mathrm{PPh}_{3}\right)_{2}\right] \mathrm{ClO}_{4} \cdot \mathrm{H}_{2} \mathrm{O}\left(\mathbf{5} \cdot \mathrm{H}_{2} \mathrm{O}\right)$, were determined by a single crystal X-ray analysis. The geometry of these compounds is square-planar with the $\mathrm{NiS}_{2} \mathrm{PN}(\mathbf{4})$ and $\mathrm{NiS}_{2} \mathrm{P}_{2}\left(\mathbf{5} \cdot \mathrm{H}_{2} \mathrm{O}\right)$ donor sets.

This work also describes the effect of the nickel(II) dithiocarbamates on the oxidation of graphite as a model study of the coal combustion. As it is commonly known, the ignition temperature of the coal combustion is one of the most important properties influencing many industrial processes. This stage can be affected by the presence of both natural and artificial impurities $[14,15]$. Formerly, several papers reported simple nickel(II) compounds, such as $\mathrm{NiO}$ (mixed with $\mathrm{KOH}$ ) or $\mathrm{Ni}\left(\mathrm{NO}_{3}\right)_{2}$ (mixed with $\mathrm{K}_{2} \mathrm{SO}_{4}$ ), as the substances accelerating graphite oxidation [16,17]. Few years ago, we decided to study the influence of the nickel(II, IV) dithiocarbamato complexes [see 13,18,19 and references cited therein] on the course of graphite oxidation. It was found that the presence of these complexes causes the ignition temperature decrease. Similar results were obtained also for the tested complexes $\mathbf{1}, \mathbf{3}, \mathbf{5}$, and $\mathbf{6}$, which were chosen as representatives of the presented compounds, as it is discussed in more detail within the framework of this paper.

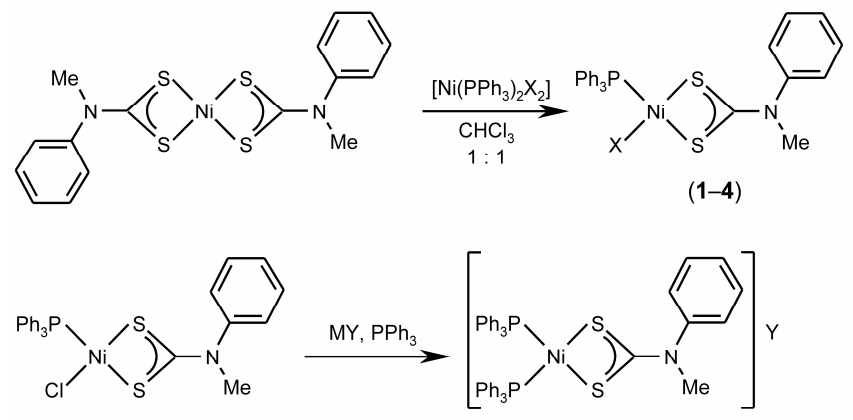

(1)

(5-7)

Scheme 1. Schematic representation of the synthetic procedures applied for the preparation of the nickel(II) complexes 1-7; X = $\mathrm{Cl}^{-}(\mathbf{1}), \mathrm{Br}^{-}(\mathbf{2}), \mathrm{I}^{-}(\mathbf{3})$ and $\mathrm{NCS}^{-}(\mathbf{4}), \mathrm{MY}=\mathrm{LiClO}_{4} \cdot 3 \mathrm{H}_{2} \mathrm{O}(\mathbf{5})$, $\mathrm{Na}\left[\mathrm{BPh}_{4}\right](\mathbf{6})$ and $\mathrm{K}\left[\mathrm{PF}_{6}\right](\mathbf{7})$.

\section{Results and Discussion}

The nickel(II) complexes 1-7 were prepared according to the synthetic strategies depicted in Scheme 1. The obtained molar conductivity values (Table 1) indicate that complexes 1-4 dissolved in acetone behave as non-electrolytes [20], which indirectly proved the coordination of the $\mathrm{Cl}^{-}(\mathbf{1}), \mathrm{Br}^{-}$ (2), $\mathrm{I}^{-}(3)$ and $\mathrm{NCS}^{-}(4)$ anions to the $\mathrm{Ni}(\mathrm{II})$ atom. On the other hand, the molar conductivity values of the remaining complexes proved the ionic nature (1:1 electrolyte type) in acetone $(\mathbf{5})$ or DMF $(\mathbf{6}, 7)$ solutions, which means that the $\mathrm{ClO}_{4}^{-}(\mathbf{5}), \mathrm{BPh}_{4}^{-}(\mathbf{6})$ and $\mathrm{PF}_{6}^{-}(7)$ anions are situated outside of the inner coordination sphere within the structure of the discussed complexes. The results of the room temperature magnetochemical measurements determined the prepared compounds to be diamagnetic, and thus, suggested on square-planar geometries in the vicinity of the central atom.

Table 1: The results of molar conductivity measurements, IR, UV-Vis and ${ }^{31} \mathrm{P}\{\mathrm{H}\}$-NMR spectroscopy of the complexes 1-7

\begin{tabular}{|c|c|c|c|c|c|c|}
\hline & $\lambda_{\mathrm{M}}{ }^{\mathrm{a}}$ & $\begin{array}{l}\text { IR }(\mathrm{cm} \\
v(\mathrm{C} \cdots \mathrm{S}\end{array}$ & $\begin{array}{l}-1)^{b} \\
v\left(C^{\cdots}-N\right)\end{array}$ & other & $\begin{array}{l}\text { UV-Vis } \\
\left(\mathrm{cm}^{-1}\right)^{\mathrm{c}}\end{array}$ & $\begin{array}{l}{ }^{31} \mathrm{P}\{\mathrm{H}\}-\mathrm{NMR} \\
\delta^{\mathrm{d}}(\mathrm{ppm})\end{array}$ \\
\hline \multirow[t]{3}{*}{1} & 2.2 & $990 \mathrm{~m}$ & $1510 \mathrm{~m}$ & & 19200 & $21.1 \mathrm{~s}$ \\
\hline & & & & & 25200 & \\
\hline & & & & & 29000 & \\
\hline \multirow[t]{3}{*}{2} & 2.1 & $996 \mathrm{~m}$ & $1520 \mathrm{~m}$ & & 18900 & $24.8 \mathrm{~s}$ \\
\hline & & & & & 25000 & \\
\hline & & & & & 29000 & \\
\hline \multirow[t]{2}{*}{3} & 9.3 & $998 \mathrm{~m}$ & $1520 \mathrm{~m}$ & & 18400 & $31.6 \mathrm{~s}$ \\
\hline & & & & & 31400 & \\
\hline \multirow[t]{2}{*}{4} & 1.7 & $996 \mathrm{~m}$ & $1528 \mathrm{~m}$ & $840 m v(C-S)$ & 20400 & $22.8 \mathrm{~s}$ \\
\hline & & & & $2092 s v(C \equiv N)$ & 29000 & \\
\hline \multirow[t]{2}{*}{5} & 99.0 & $996 w$ & $1542 \mathrm{~m}$ & $622 \mathrm{~m} \mathrm{v}_{4}\left(\mathrm{ClO}_{4}^{-}\right)$ & 19900 & $32.0 \mathrm{~s}$ \\
\hline & & & & $1088 \mathrm{~s} v_{3}\left(\mathrm{ClO}_{4}^{-}\right)$ & 31000 & \\
\hline \multirow[t]{2}{*}{6} & 77.3 & $990 \mathrm{~m}$ & $1536 \mathrm{~s}$ & & 20700 & $32.1 \mathrm{~s}$ \\
\hline & & & & & 30900 & \\
\hline \multirow[t]{2}{*}{7} & 66.9 & $996 \mathrm{~m}$ & $1540 \mathrm{~m}$ & $836 \mathrm{~m} \mathrm{v} v_{4}\left(\mathrm{PF}_{6}^{-}\right)$ & 19800 & $32.0 \mathrm{~s}$, \\
\hline & & & & & 29300 & $-143.6 \mathrm{sp}$ \\
\hline
\end{tabular}

[a] $\mathrm{S} \mathrm{cm}^{2} \mathrm{~mol}^{-1}\left(10^{-3} \mathrm{M}\right.$ acetone solutions for 1-5 and $5 \times 10^{-4} \mathrm{M}$ DMF solutions for 6 and 7); [b] $\mathrm{KBr}$ pellets $(\mathrm{w}=$ weak, $\mathrm{m}=$ middle, $\mathrm{s}=$ strong); [c] nujol technique; [d] $\mathrm{CDCl}_{3}$ solutions $(\mathrm{s}=$ singlet, $\mathrm{sp}=$ septuplet)

\section{Spectroscopic Characterization}

The $\mathrm{PPh}_{3}$ signals in the ${ }^{31} \mathrm{P}\left\{{ }^{1} \mathrm{H}\right\}$-NMR spectra of the $\mathrm{CDCl}_{3}$ solutions of 1-7 were found in the range of 21.1$32.1 \mathrm{ppm}$ (Table 1). These values differ significantly from that of $-4.52 \mathrm{ppm}$ determined for the free $\mathrm{PPh}_{3}$ molecule, which is caused by electron density redistribution from phosphorus towards the $\mathrm{Ni}$ (II) centre as a consequence of $\mathrm{PPh}_{3}$ coordination. The spectrum of $\mathbf{7}$ contains a septuplet at $-143.6 \mathrm{ppm}$ assignable to the $\mathrm{PF}_{6}{ }^{-}$anion. It should be noted that the chemical shift values of the complexes 1-4 increased in the order $\left[\mathrm{Ni}(\mathrm{Cl})(\mathrm{BzMedtc})\left(\mathrm{PPh}_{3}\right)\right](\mathbf{1})<$ $\left[\mathrm{Ni}(\mathrm{NCS})(\mathrm{BzMedtc})\left(\mathrm{PPh}_{3}\right)\right](\mathbf{4})<\left[\mathrm{Ni}(\mathrm{Br})(\right.$ BzMedtc $\left.)\left(\mathrm{PPh}_{3}\right)\right]$ (2) $<\left[\mathrm{Ni}(\mathrm{I})(\mathrm{BzMedtc})\left(\mathrm{PPh}_{3}\right)\right](3)$, which agrees with the results reported for the nickel(II) complexes with $N$-benzyl$\mathrm{N}$-butyldithiocarbamate [12].

The maxima observed in the IR spectra of the nickel(II) complexes 1-7 at $990-998 \mathrm{~cm}^{-1}$, and $1510-1542 \mathrm{~cm}^{-1}$ (see Table 1) are typical for the $v\left(\mathrm{C}^{\cdots} \mathrm{S}\right)$, and $v\left(\mathrm{C}^{\cdots}-\mathrm{N}\right)$ vibrations of the dithiocarbamate moiety, respectively $[21,22]$. The 
peak of the $v(C \cdots S)$ stretching vibration is not split, which supports the bidentate coordination of the BzMedtc anion. The peaks of the $v(\mathrm{C} \equiv \mathrm{N})$ and $v(\mathrm{C}-\mathrm{S})$ vibrations of the $\mathrm{NCS}^{-}$ anion were observed in the IR spectrum of 4 . The ionic nature of the perchlorate anion in the complex $\mathbf{5}$, can be supported by two undivided peaks at 622 and $1088 \mathrm{~cm}^{-1}$ [23]. The same conclusion can be made for the complex 7 , whose IR spectrum contains the non-split peak at $836 \mathrm{~cm}^{-1}$ assignable to $v\left(\mathrm{PF}_{6}^{-}\right)$, which again indicates its ionic nature [24].

Table 2. Crystal data and structure refinements for [Ni(NCS)(BzMedtc) $\left.\left(\mathrm{PPh}_{3}\right)\right]$ (4) $\left[\mathrm{Ni}(\mathrm{BzMedtc})\left(\mathrm{PPh}_{3}\right)_{2}\right] \mathrm{ClO}_{4} \cdot \mathrm{H}_{2} \mathrm{O}\left(\mathbf{5} \cdot \mathrm{H}_{2} \mathrm{O}\right)$

\begin{tabular}{lll}
\hline Compound & $\mathbf{4}$ & $\mathbf{5} \cdot \mathrm{H}_{2} \mathrm{O}$ \\
\hline Empirical formula & $\mathrm{C}_{28} \mathrm{H}_{25} \mathrm{~N}_{2} \mathrm{NiPS}_{3} \mathrm{C}_{45} \mathrm{H}_{42} \mathrm{ClNNiO}_{5} \mathrm{P}_{2} \mathrm{~S}_{2}$ \\
Formula weight & 575.36 & 897.02 \\
Temperature $(\mathrm{K})$ & $113(2)$ & $110(2)$
\end{tabular}

Temperature $(\mathrm{K})$

$113(2) \quad 110(2)$

Wavelength $(\mathrm{A})$

Crystal system

Space group

$a(\AA)$

$b(\AA)$

$c(\AA)$

$\alpha\left(^{\circ}\right)$

$\beta\left(^{\circ}\right)$

$\gamma\left({ }^{\circ}\right)$

$V\left(\AA^{3}\right)$

$Z, D_{\text {calc }}\left(\mathrm{g} \mathrm{cm}^{-3}\right)$

Absorption coefficient

Crystal size (mm)

$F(000)$

Monoclinic

Triclinic

$P 2_{1} / n$

$P-1$

13.6177(3)

$11.47995(13)$

$10.3556(2)$

19.1287(4)

13.24049(16)

90

$15.02884(19)$

$92.4015(18) \quad 84.5683(10)$

$90 \quad 87.3995(9)$

2695.6(9) 2141.23(4)

4, $1.418 \quad 2,1.391$

$1.032 \mathrm{~mm}^{-1} \quad 0.734 \mathrm{~mm}^{-1}$

$0.30 \times 0.25 \times 0.250 .40 \times 0.35 \times 0.30$

$1192 \quad 932$

$\theta$ range for data collection $\left({ }^{\circ}\right) 2.90 \leq \theta \leq 25.00 \quad 3.03 \leq \theta \leq 25.00$

Index ranges $(h, k, l)$

$-16 \leq h \leq 16 \quad-13 \leq h \leq 13$

$-9 \leq k \leq 12 \quad-15 \leq k \leq 15$

$-22 \leq l \leq 22$

Reflections collected/unique $22656 / 4743$

$\left(R_{\text {int }}\right)$

(0.0246)

$-17 \leq l \leq 15$

Max./min. transmission

Data/restraints/parameters

Goodness-of-fit on $F^{2}$

.7825/0.7471

$18531 / 7526$

Final $R$ indices $[I>2 \sigma(I)]$

1.065

$0.8099 / 0.7578$

$R_{1}=0.0282, \quad R_{1}=0.0342$,

$\mathrm{w} R_{2}=0.0673 \quad \mathrm{w} R_{2}=0.1009$

$R$ indices (all data)

$R_{1}=0.0366, \quad R_{1}=0.0388$,

$\mathrm{w} R_{2}=0.0692 \quad \mathrm{w} R_{2}=0.1031$

$\begin{array}{lll}\text { Largest peak/hole }\left(\mathrm{e} \AA^{-3}\right) & 0.344 /-0.212 & 1.343 \text { and }-0.611\end{array}$

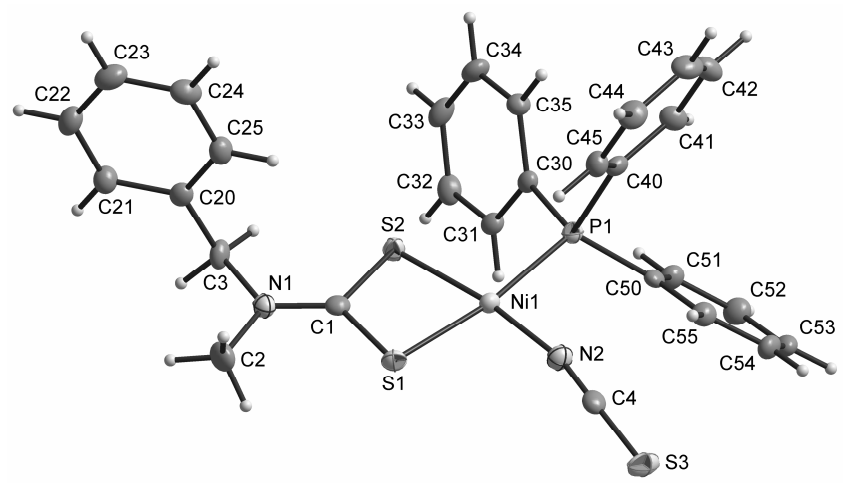

Figure 1. The molecular structure of [Ni(BzMedtc) $\left.\left(\mathrm{PPh}_{3}\right)(\mathrm{NCS})\right]$ complex (4) with non-hydrogen atoms drawn as thermal ellipsoids at the $50 \%$ probability level.

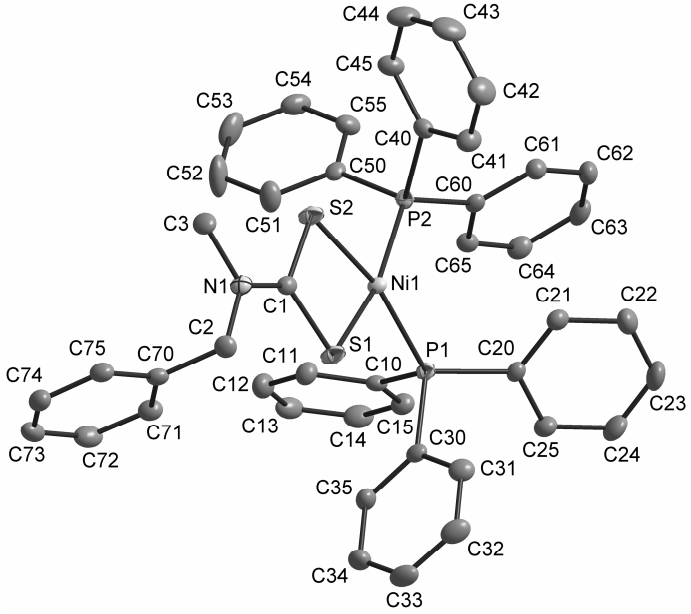

$\begin{array}{lll}\text { Figure 2. The molecular } & \text { structure of } \\ {\left[\mathrm{Ni}(\mathrm{BzMedtc})\left(\mathrm{PPh}_{3}\right)_{2}\right] \mathrm{ClO}_{4} \cdot \mathrm{H}_{2} \mathrm{O}} & \left(\mathbf{5} \cdot \mathrm{H}_{2} \mathrm{O}\right) & \text { with non-hydrogen }\end{array}$ atoms drawn as thermal ellipsoids at the $50 \%$ probability level. The hydrogen atoms, perchlorate anion and water molecule of crystallization omitted for clarity.

Diffuse-reflectance electronic spectra of the prepared complexes 1-7 support the assumption of the square-planar geometry in the vicinity of the central $\mathrm{Ni}(\mathrm{II})$ atom. Absorption maxima at the $18400-20700 \mathrm{~cm}^{-1}$ region may be attributed to the ${ }^{1} \mathrm{~A}_{1 \mathrm{~g}} \rightarrow{ }^{1} \mathrm{~B}_{1 \mathrm{~g}}$ transition of the squareplanar nickel(II) complexes [25,26]. The next maxima, also assignable to the $d$ - $d$ transitions, were found for the complexes $1\left(25200 \mathrm{~cm}^{-1}\right)$ and $\mathbf{2}\left(25000 \mathrm{~cm}^{-1}\right)$. The maxima above $29000 \mathrm{~cm}^{-1}$ are probably connected with the intraligand charge-transfer transitions in the $\mathrm{S}_{2} \mathrm{CN}$ moiety [27].

\section{$X$-ray Structure of [Ni(NCS)(BzMedtc) $\left.\left(\boldsymbol{P P h}_{3}\right)\right](4)$ and $\left[\mathrm{Ni}(\mathrm{BzMedtc})\left(\mathrm{PPh}_{3}\right)_{2}\right] \mathrm{ClO}_{4} \cdot \mathrm{H}_{2} \mathrm{O}\left(5 \cdot \mathrm{H}_{2} \mathrm{O}\right)$}

The X-ray structure of the title complexes 4 (Figure 1) and $5 \cdot \mathrm{H}_{2} \mathrm{O}$ (Figure 2 ) was determined by a single crystal X-ray analysis. The crystal data and structure refinements are given in Table 2, while the selected bond lengths and angles are summarized in Table 3.

The central Ni(II) ion of the complex 4 (Figure 1) is fourcoordinated by $\mathrm{PPh}_{3}$, the isothiocyanate anion, and the bidentate-coordinated $N$-benzyl- $N$-methyldithiocarbamate anion (BzMedtc). The atoms of a $\mathrm{NiS}_{2} \mathrm{NP}$ chromophore are arranged in the distorted square-planar geometry around the metal centre (Table 3). The Ni-S bond lengths of the title complex correlate well with the mean value of $2.204 \AA$ (2.155-2.258 $\AA$ interval) determined for this band for the 116 square-planar nickel complexes involving bidentate-coordinated dithiocarbamato S-donor ligands, which have been up to now deposited in the Cambridge Structural Database (CSD) [9].

The well-known delocalization of $\pi$-electron density within the $\mathrm{S}_{2} \mathrm{CN}$ moiety of the dithiocarbamate anion was observed for 4 , since the $\mathrm{C}-\mathrm{N}$ and $\mathrm{C}-\mathrm{S}$ bond lengths of the 
studied compound (Table 2) were found to be significantly shorter compared to the single $\mathrm{C}-\mathrm{N}(1.47 \AA)$ and $\mathrm{C}-\mathrm{S}(1.81$ $\AA$ ) $\sigma$-bond lengths [28]. Further, the $\mathrm{C}-\mathrm{S}$ and $\mathrm{C}-\mathrm{N}$ bond length values of BzMedtc are comparable with those of the transition metal (TM) complexes involving the (TM) $\mathrm{S}_{2} \mathrm{CNR}_{2}$ moiety and deposited within the CSD, which equal $1.717 \AA$, and $1.326 \AA$, respectively.

The $\mathrm{S} 1$ atom is the most deviated one [0.0454(5) $\AA$ ] from the plane created through the Ni1, S1, S2, P1 and N2 atoms of the chromophore. Further, the described plane forms the dihedral angle of $83.10(5)^{\circ}$ with the benzene ring of the BzMedtc molecule and dihedral angles of $67.90(5)^{\circ}$, $69.63(5)^{\circ}$ and $47.85(4)^{\circ}$ with the benzene rings of $\mathrm{PPh}_{3}$ containing the $\mathrm{C} 30, \mathrm{C} 40$, and $\mathrm{C} 50$ atoms, respectively. Mutual orientation of the phenyl groups of $\mathrm{PPh}_{3}$ within the molecular structure of 4 can be described by the 67.64(6) ${ }^{\circ}$ (between benzene rings containing $\mathrm{C} 30$ and $\mathrm{C} 40$ ), 66.06(6) ${ }^{\circ}$ (between benzene rings containing $\mathrm{C} 30$ and $\mathrm{C} 50$ ) and 76.53(6) ${ }^{\circ}$ (between benzene rings containing C40 and C50) dihedral angles. The $\mathrm{C}-\mathrm{H} \cdots \mathrm{C}, \mathrm{C}-\mathrm{H} \cdots \mathrm{S}$ and $\mathrm{C} \cdots \mathrm{C}$ types of the intramolecular non-bonding interactions were detected to stabilize the crystal structure of $\mathbf{4}$ (see Table 4). No typical hydrogen bond is present within the structure of discussed complex.

Table 3: Selected bond lengths $(\AA)$ and angles $\left({ }^{\circ}\right)$ for the complexes [Ni(NCS)(BzMedtc) $\left.\left(\mathrm{PPh}_{3}\right)\right]$ (4) and [Ni(BzMedtc) $\left.\left(\mathrm{PPh}_{3}\right)_{2}\right] \mathrm{ClO}_{4} \cdot \mathrm{H}_{2} \mathrm{O}\left(\mathbf{5} \cdot \mathrm{H}_{2} \mathrm{O}\right)$

\begin{tabular}{|c|c|c|}
\hline Compound & 4 & $5 \cdot \mathrm{H}_{2} \mathrm{O}$ \\
\hline \multicolumn{3}{|l|}{ Bond Lengths } \\
\hline Ni1-S1 & $2.2245(5)$ & $2.2154(6)$ \\
\hline Ni1-S2 & $2.1758(5)$ & $2.2257(6)$ \\
\hline Ni1-P1 & $2.2162(5)$ & $2.2165(6)$ \\
\hline $\mathrm{Ni1}-\mathrm{P} 2$ & - & $2.2316(6)$ \\
\hline $\mathrm{Ni1}-\mathrm{N} 2$ & $1.8564(17)$ & - \\
\hline $\mathrm{C} 1-\mathrm{S} 1$ & $1.7125(19)$ & $1.731(2)$ \\
\hline $\mathrm{C} 1-\mathrm{S} 2$ & $1.7214(19)$ & $1.721(2)$ \\
\hline $\mathrm{C} 1-\mathrm{N} 1$ & $1.306(2)$ & $1.307(3)$ \\
\hline $\mathrm{N} 2-\mathrm{C} 4$ & $1.163(2)$ & - \\
\hline $\mathrm{C} 4-\mathrm{S} 3$ & $1.621(2)$ & - \\
\hline \multicolumn{3}{|l|}{ Bond Angles } \\
\hline S1-Ni1-S2 & 78.643(19) & $78.29(2)$ \\
\hline S1-Ni1-P1 & $171.63(2)$ & $91.28(2)$ \\
\hline $\mathrm{S} 1-\mathrm{Ni} 1-\mathrm{N} 2$ & $92.06(5)$ & - \\
\hline S1-Ni1-P2 & - & $167.08(2)$ \\
\hline S2-Ni1-P1 & $93.384(19)$ & $167.76(2)$ \\
\hline S2-Ni1-P2 & - & $88.91(2)$ \\
\hline S2-Ni1-N2 & $170.70(5)$ & - \\
\hline P1-Ni1-N2 & $95.91(5)$ & - \\
\hline $\mathrm{P} 1-\mathrm{Ni1}-\mathrm{P} 2$ & - & $101.24(2)$ \\
\hline Ni1-S1-C1 & $85.71(7)$ & $86.52(8)$ \\
\hline Ni1-S2-C1 & $87.04(7)$ & $86.42(8)$ \\
\hline $\mathrm{S} 1-\mathrm{C} 1-\mathrm{S} 2$ & $108.60(11)$ & 108.61(12) \\
\hline $\mathrm{S} 1-\mathrm{C} 1-\mathrm{N} 1$ & $125.67(15)$ & $126.50(17)$ \\
\hline $\mathrm{S} 2-\mathrm{C} 1-\mathrm{N} 1$ & $125.73(15)$ & $124.89(17)$ \\
\hline $\mathrm{Ni1}-\mathrm{N} 2-\mathrm{C} 4$ & $167.29(16)$ & - \\
\hline $\mathrm{N} 2-\mathrm{C} 4-\mathrm{S} 3$ & $178.52(19)$ & - \\
\hline
\end{tabular}

In the case of $\mathbf{5} \cdot \mathrm{H}_{2} \mathrm{O}$, the $\mathrm{Ni}(\mathrm{II})$ ion is four-coordinated in the distorted square-planar geometry (Figure 2), similarly to the above described structure of complex 4 , by the bidentate-coordinated S-donor BzMedtc ligand and by two $\mathrm{P}$-donor $\mathrm{PPh}_{3}$ molecules. Selected bond lengths and angles are given in Table 3. The positive charge of the $\left[\mathrm{Ni}(\mathrm{BzMedtc})\left(\mathrm{PPh}_{3}\right)_{2}\right]^{+}$cation is compensated by the perchlorate anion; the shortest $\mathrm{Ni1} \cdots \mathrm{Cl} 1$ distance equals 7.131(2) ^.

Table 4 Selected intramolecular non-bonding interactions and their parameters $\left(\AA,^{\circ}\right)$ determined for the complexes $\mathbf{4}$ and $\mathbf{5} \cdot \mathrm{H}_{2} \mathrm{O}$

\begin{tabular}{lcccc}
\hline $\mathrm{D}-\mathrm{H} \cdots \mathrm{A}$ & $d(\mathrm{D}-\mathrm{H})$ & $d(\mathrm{H} \cdots \mathrm{A})$ & $d(\mathrm{D} \cdots \mathrm{A})$ & $<(\mathrm{DHA})$ \\
\hline $\mathbf{4}$ & & & & \\
$\mathrm{C} 3-\mathrm{H} 3 \mathrm{~A} \cdots \mathrm{S} 3^{\mathrm{i}}$ & 0.990 & $2.9234(6)$ & $3.666(2)$ & $132.43(12)$ \\
$\mathrm{C} 34-\mathrm{H} 34 \mathrm{~A} \cdots \mathrm{S} 2^{\mathrm{ii}}$ & 0.950 & $2.9389(5)$ & $3.717(2)$ & $139.90(12)$ \\
$\mathrm{C} 32-\mathrm{H} 32 \mathrm{~A} \cdots \mathrm{S} 3^{\mathrm{iii}}$ & 0.950 & $2.8695(6)$ & $3.814(2)$ & $172.48(12)$ \\
$\mathrm{C} 31-\mathrm{H} 31 \mathrm{~A} \cdots \mathrm{S} 1^{\mathrm{iii}}$ & 0.950 & $2.9701(6)$ & $3.883(2)$ & $161.56(12)$ \\
$\mathrm{C} 2 \cdots \mathrm{C} 32$ & & & $3.307(3)$ & \\
$\mathbf{5} \cdot \mathrm{H}_{2} \mathrm{O}$ & & & & \\
$\mathrm{C} 74-\mathrm{H} 74 \mathrm{~A} \cdots \mathrm{C} 32^{\mathrm{iv}}$ & 0.950 & $2.771(3)$ & $3.678(4)$ & $160.13(16)$ \\
$\mathrm{C} 72-\mathrm{H} 72 \mathrm{~A} \cdots \mathrm{C} 54^{\mathrm{v}}$ & 0.950 & $2.781(2)$ & $3.554(3)$ & $139.11(16)$ \\
$\mathrm{C} 2-\mathrm{H} 2 \mathrm{~B} \cdots \mathrm{C} 74^{\text {iv }}$ & 0.990 & $2.844(2)$ & $3.771(3)$ & $156.25(14)$ \\
$\mathrm{C} 14-\mathrm{H} 14 \mathrm{~A} \cdots \mathrm{C} 33^{\mathrm{vi}}$ & 0.950 & $2.746(3)$ & $3.666(4)$ & $163.31(16)$ \\
$\mathrm{C} 13-\mathrm{H} 13 \mathrm{~A} \cdots \mathrm{C} 3^{\mathrm{v}}$ & 0.950 & $2.879(2)$ & $3.815(3)$ & $168.16(14)$ \\
$\mathrm{C} 44-\mathrm{H} 44 \mathrm{~A} \cdots \mathrm{C} 64^{\mathrm{vii}}$ & 0.950 & $2.872(3)$ & $3.653(4)$ & $140.17(16)$ \\
$\mathrm{C} 13 \cdots \mathrm{C} 71^{\mathrm{v}}$ & & & $3.262(4)$ & \\
$\mathrm{C} 70 \cdots \mathrm{C} 70^{\mathrm{iv}}$ & & & $3.391(3)$ & \\
\hline
\end{tabular}

Symmetry codes: (i) $\mathrm{x}+0.5,0.5-\mathrm{y}, \mathrm{z}-0.5$; (ii) $1-\mathrm{x}, 1-\mathrm{y}, 1-\mathrm{z}$; (iii) $1.5-\mathrm{x}, \mathrm{y}+0.5,1.5-\mathrm{z}$; (iv) $-\mathrm{x},-\mathrm{y},-\mathrm{z}$; (v) $-\mathrm{x}, 1-\mathrm{y},-\mathrm{z}$; (vi) 1 $-\mathrm{x}, 1-\mathrm{y},-\mathrm{z} ;$ (vii) $-\mathrm{x}, 1-\mathrm{y}, 1-\mathrm{z}$

As it has been already mentioned in the case of complex $\mathbf{4}$, the bond lengths within the $\mathrm{NiS}_{2} \mathrm{CN}$ moiety of both structures show on electron density redistribution in connection with $\pi$-electron density delocalization (see the $\mathrm{C}-\mathrm{S}$ and $\mathrm{C}-\mathrm{N}$ bond lengths in Table 3 ). As for the $\mathrm{Ni}-\mathrm{P}$ bonds of $\mathbf{5}$, their lengths are in good agreement with the mean value of $2.208 \AA(2.175-2.252 \AA$ interval $)$ as determined from $36 \mathrm{X}$-ray structures of tetra-coordinated nickel dithiocarbamato complexes involving at least one $\mathrm{PPh}_{3}$ ligand and deposited within the CSD.

The S2 atom is the most deviated one [0.0903(6) $\AA$ ] from the plane created through the atoms of the chromophore. The dihedral angles between this plane and benzene rings involving $\mathrm{C} 10, \mathrm{C} 20, \mathrm{C} 30, \mathrm{C} 40, \mathrm{C} 50, \mathrm{C} 60$, and $\mathrm{C} 70$ are $86.39(5)^{\circ}, \quad 58.49(7)^{\circ}, \quad 87.97(5)^{\circ}, \quad 70.52(5)^{\circ}, \quad 71.64(5)^{\circ}$, $63.60(6)^{\circ}$, and $71.98(5)^{\circ}$, respectively. Non-bonding interactions of the $\mathrm{C}-\mathrm{H} \cdots \mathrm{C}$ and $\mathrm{C} \cdots \mathrm{C}$ types $(\mathrm{C}-\mathrm{H} \cdots \mathrm{O}$ interactions with the distorted perchlorate anion and water molecule of crystallization are disregarded) were found in the crystal structure of the discussed nickel(II) complex (Table 4).

\section{TG/DTA Thermal Analysis}

The thermal properties of the prepared nickel(II) complexes were studied by TG and DTA methods. The TG and DTA curves of $\mathbf{1}$ and $\mathbf{6}$ are depicted in Figure 3. Although the chemical composition of these complexes is different, their thermal decomposition proceeded in a similar manner as indicated by analogical shapes of the TG curves. In cases of 2,3 and $\mathbf{6}$, the sharp exo-effects with maxima at $188^{\circ} \mathrm{C}, \quad 193^{\circ} \mathrm{C}$, and $188^{\circ} \mathrm{C}$, respectively, were accompanied by mass increase on the TG curves, which can be attributed to the oxygen atom insertion into the $\mathrm{Ni}-\mathrm{P}$ bond [29]. This effect was not registered on the TG curves of the remaining complexes, where the oxygen atom 


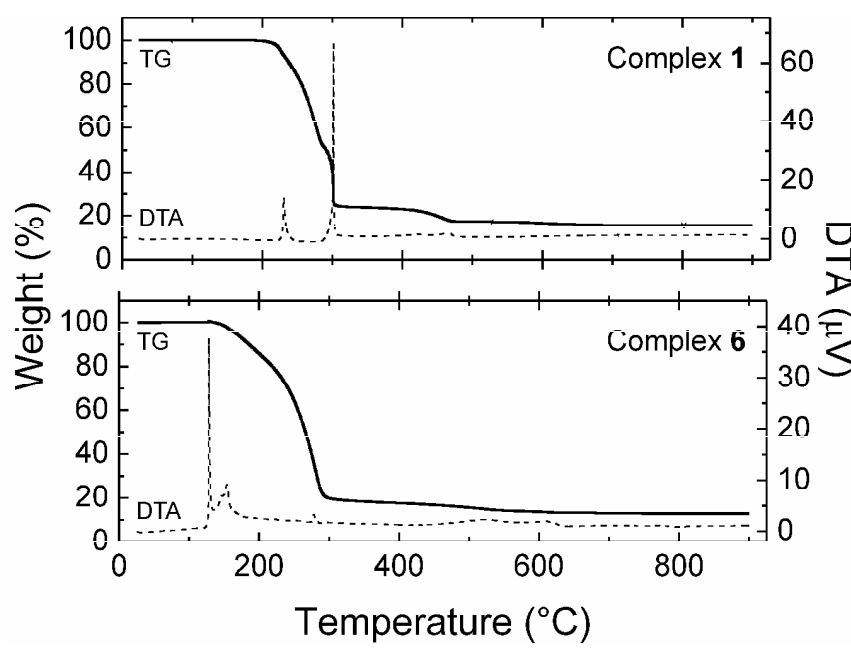

Figure 3. TG/DTA curves for complexes 1 and $\mathbf{6}$.

insertion is most likely combined with the decomposition of the organic parts of the studied complexes.

The final products of the TG studies $\left(900{ }^{\circ} \mathrm{C}\right)$ were studied by X-ray powder diffraction (XRD). NiO (PDF-4 No. 01-089-7130) was determined as the final product of the thermal decomposition of 1-4. In the cases of the complexes 6 and 7, the mixtures with significant predominance of $\mathrm{NiO}$ were detected. The final product of the TG thermal study of 6 also contains NiS (PDF-4 No. 4-004-5027) and $\mathrm{Ni}_{3} \mathrm{~B}_{2} \mathrm{O}_{6}$ (PDF-4 No. 4-008-3203), and some peaks could not be assigned. As for the complex 7, $\mathrm{Ni}_{2} \mathrm{P}_{2} \mathrm{O}_{7}$ (PDF-4 No. 01-074-1604) and $\mathrm{Ni}_{3}\left(\mathrm{PO}_{4}\right)_{2}$ (PDF-4 No. 01-072-3977) were detected by a XRD, while some peaks were not assigned.

\section{Catalytic Influence of the Complexes on Graphite Oxidation}

The influence of the presence of the representative complexes $\mathbf{1}, \mathbf{3}, \mathbf{5}$ and $\mathbf{6}$ on graphite oxidation were studied. The results, summarized in Figure 4 (obtained DTG curves) and Table 5 (obtained data), showed an positive influence on graphite oxidation, because the ignition temperature significantly decreased (by about $64-99{ }^{\circ} \mathrm{C}$ ) after the addition of the tested nickel(II) complexes to a pure graphite.

Pure graphite oxidation proceeds in one step, while in the cases of its mixtures with the tested complexes, two steps in a larger temperature interval were detected on the appropriate DTG curves (Table 5). The first step takes place at lower temperature than pure graphite oxidation, whereas the oxidation rate maxima $\left(T_{m}\right)$ of the second step approximately correspond to pure graphite. In addition, the oxidation mechanisms of both steps are different, as it can be seen from the activation energy $(E)$ and frequency factor (A) values given in Table 5. More graphite was oxidized during the second step with higher $E$ and $A$ values.

At this point, we would like to discuss the described results of the influence on the graphite oxidation in connection with the results of TG/DTA studies. Figure 3 clearly shows that the thermal decomposition of the nickel(II) complexes is almost completely finished at the temperature of ca. $700{ }^{\circ} \mathrm{C}$ and the weight loss above this temperature is insignificant. Based on this statement it may be concluded that not directly the discussed nickel(II) $\mathrm{N}$ benzyl- $N$-methyldithiocarbamato complexes, but the products of their thermal decomposition processes, affected graphite oxidation.

Table 5: Characteristic temperatures and kinetic parameters of catalytic influence on graphite given for pure graphite and its mixtures with nickel(II) complexes 1, 3, 5 and $\mathbf{6}$

\begin{tabular}{llllllll}
\hline Sample & $T\left({ }^{\circ} \mathrm{C}\right)$ & $T_{m}\left({ }^{\circ} \mathrm{C}\right)$ & Step & $n$ & $A\left(\mathrm{~s}^{-1}\right)$ & $E$ & $w(\%)$ \\
\hline Graphite & $778-859$ & 832 & & 0.7 & $1.97 \times 10^{9}$ & 247 & \\
$\mathbf{1}$ & $679-838$ & 792 & I & 1.3 & $3.62 \times 10^{7}$ & 190 & 43.58 \\
& & & II & 0.9 & $1.09 \times 10^{9}$ & 235 & 56.42 \\
$\mathbf{3}$ & $696-879$ & 838 & I & 0.9 & $4.08 \times 10^{6}$ & 174 & 34.48 \\
& & & II & 0.9 & $9.10 \times 10^{7}$ & 220 & 65.52 \\
$\mathbf{5}$ & $693-860$ & 815 & I & 1.0 & $1.47 \times 10^{7}$ & 183 & 36.06 \\
& & & II & 1.0 & $4.08 \times 10^{9}$ & 250 & 63.94 \\
$\mathbf{6}$ & $714-861$ & 812 & I & 0.8 & $5.88 \times 10^{6}$ & 176 & 23.48 \\
& & & II & 1.1 & $1.17 \times 10^{9}$ & 238 & 76.52 \\
\hline
\end{tabular}

$T=$ temperature range of oxidation; $T_{m}=$ oxidation rate maximum; $n=$ reaction order; $A=$ frequency factor; $E=$ activation energy $(\mathrm{kJ}$ $\left.\mathrm{mol}^{-1}\right) ; w=$ mass of sample oxidized

In connection with the above-mentioned facts, the tested complexes (except of 5) were heated in situ to the temperatures corresponding to the beginning and end of graphite oxidation (see Table 5). The products of thermal decomposition relating to the mentioned temperatures were analysed by XRD. As for $\mathbf{1 - 4}$, pure $\mathrm{NiO}$ was identified at both temperatures (Figure 5). The slight differences in the $2 \theta$ values were caused by a dilatation of the sample due to different measurement temperature. On the other hand, the mixtures of $\mathrm{NiO}, \mathrm{NiS}$ and $\mathrm{Ni}_{3} \mathrm{~B}_{2} \mathrm{O}_{6}$ (for 6 ) and $\mathrm{Ni}_{2} \mathrm{P}_{2} \mathrm{O}_{7}$ and $\mathrm{Ni}_{3}\left(\mathrm{PO}_{4}\right)_{2}$ (for 7) were detected by an XRD (Figure 5). Their quantitative composition was similar at both temperatures. Some peaks could not be assigned again.

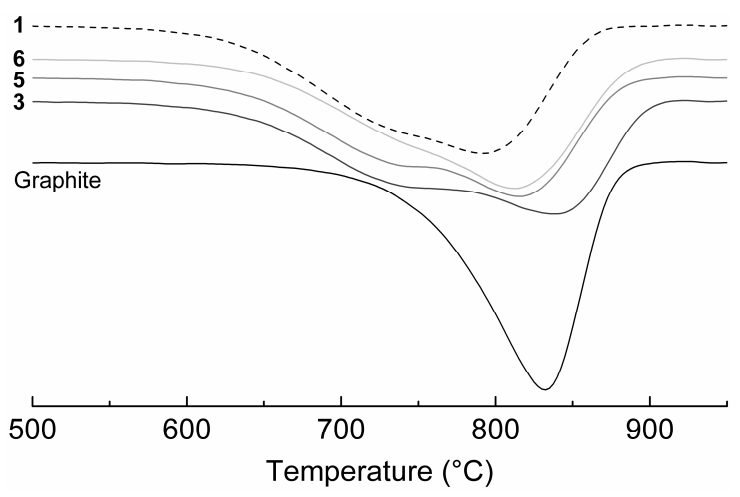

Figure 4. DTG curves obtained for pure graphite (black lines) and its mixture with the complexes $\mathbf{1}$ (black dashed lines), $\mathbf{3}$ (dark gray line), $\mathbf{5}$ (gray line) and $\mathbf{6}$ (light gray line); the tangent method was employed to determine the initial temperatures of the graphite oxidation 


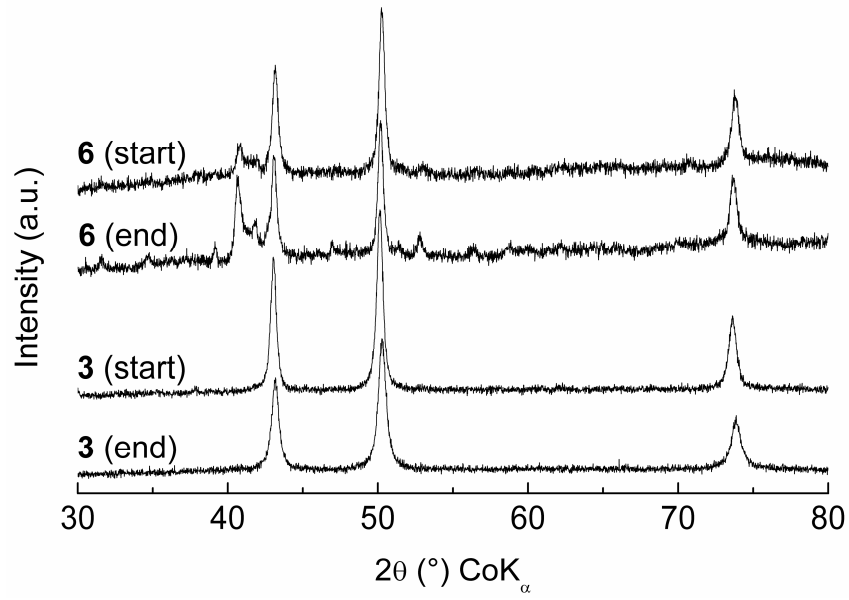

Figure 5. XRD patterns of the thermal decomposition products of the complexes $\mathbf{3}$ and $\mathbf{6}$. The detected diffraction lines belong to $\mathrm{NiO}$ for 3, and $\mathrm{NiO}, \mathrm{NiS}$ and $\mathrm{Ni}_{3} \mathrm{~B}_{2} \mathrm{O}_{6}$ for 6 ; the start and end temperatures are given in Table 5.

\section{Conclusions}

Seven nickel(II) complexes of the $\left[\mathrm{Ni}(\mathrm{BzMedtc})\left(\mathrm{PPh}_{3}\right) \mathrm{X}\right]$ (1-4) and $\left[\mathrm{Ni}(\mathrm{BzMedtc})\left(\mathrm{PPh}_{3}\right)_{2}\right] \mathrm{Y}$ (5-7) compositions were synthesized; $\mathrm{X}=\mathrm{Cl}^{-}$for $\mathbf{1}, \mathrm{Br}^{-}$for $\mathbf{2}, \mathrm{I}^{-}$for $\mathbf{3}$ and $\mathrm{NCS}^{-}$for $\mathbf{4}$, $\mathrm{Y}=\mathrm{ClO}_{4}^{-}$for $5, \mathrm{BPh}_{4}^{-}$for $\mathbf{6}$ and $\mathrm{PF}_{6}^{-}$for 7 ). The obtained powder products were fully characterized by elemental analysis, magnetochemical and molar conductivity measurements, thermal analysis and spectroscopic methods (IR, UV-Vis, ${ }^{31} \mathrm{P}\left\{{ }^{1} \mathrm{H}\right\}$-NMR). The molecular structures of the complexes [Ni(BzMedtc) $\left.\left(\mathrm{PPh}_{3}\right)(\mathrm{NCS})\right]$ (4) and $\left[\mathrm{Ni}(\mathrm{BzMedtc})\left(\mathrm{PPh}_{3}\right)_{2}\right] \mathrm{ClO}_{4} \cdot \mathrm{H}_{2} \mathrm{O} \quad\left(\mathbf{5} \cdot \mathrm{H}_{2} \mathrm{O}\right)$ were determined by a single crystal $\mathrm{X}$-ray analysis, which proved the distorted square-planar geometry with the bidentatecoordinated S-donor BzMedtc anion accompanied by $\mathrm{PPh}_{3}$ and $\mathrm{NCS}^{-}(\mathbf{4})$ or by two $\mathrm{PPh}_{3}(\mathbf{5})$. This paper also describes the significant catalytic influence of the thermal degradation products of the selected complexes $\mathbf{1 , 3 , 5}$, and $\mathbf{6}$ on graphite oxidation.

\section{Experimental Section}

\section{Materials and General Methods}

Chemicals and solvents were purchased from Sigma-Aldrich Co., Acros Organics Co., Lachema Co. and Fluka Co. and they were used as received. The starting compounds $\left[\mathrm{Ni}(\mathrm{BzMedtc})_{2}\right]$, $\left[\mathrm{Ni}\left(\mathrm{PPh}_{3}\right) \mathrm{Cl}_{2}\right], \quad\left[\mathrm{Ni}\left(\mathrm{PPh}_{3}\right)_{2} \mathrm{Br}_{2}\right], \quad\left[\mathrm{Ni}\left(\mathrm{PPh}_{3}\right)_{2} \mathrm{I}_{2}\right] \quad$ and $\left[\mathrm{Ni}\left(\mathrm{PPh}_{3}\right)_{2}(\mathrm{NCS})_{2}\right]$ were prepared according to the formerly reported synthetic pathways $[13,30]$.

Elemental analyses $(\mathrm{C}, \mathrm{H}, \mathrm{N})$ were performed on a Fisons EA-1 108 CHNS-O Elemental Analyzer (Thermo Scientific). The content of nickel was determined using the chelatometric titration with murexide as an indicator. Chlorine, bromine and iodine contents were determined by the Schöniger method. Diffuse-reflectance spectra were recorded on a Perkin-Elmer Lamda35 UV/Vis spectrometer using a nujol technique. IR spectra (KBr pellets) were recorded on a Perkin-Elmer Spectrum one FT-IR spectrometer in the $450-4000 \mathrm{~cm}^{-1}$ region. The molar conductivity values of $10^{-3}$ $\mathrm{M}$ acetone solutions of $\mathbf{1 - 5}$ and $5 \times 10^{-4} \mathrm{M}$
$N, N^{\prime}$-dimethylformamide (DMF) solutions of $\mathbf{6}$ and 7 were determined by an LF 330/SET conductometer (WTW GmbH) at 25 ${ }^{\circ} \mathrm{C}$. The room temperature magnetic susceptibilities were measured using the Faraday method with a laboratory designed instrument with a Sartorius 4434 MP-8 microbalance; $\mathrm{Co}\left[\mathrm{Hg}(\mathrm{NCS})_{4}\right]$ was used as a calibrant and the correction for diamagnetism was performed using Pascal constants. Simultaneous thermogravimetric (TG) and differential thermal (DTA) analyses were performed by an Exstar TG/DTA 6200 (Seiko Instruments Inc.) in a platinum crucible and dynamic air atmosphere $\left(100 \mathrm{~mL} \mathrm{~min}^{-1}\right)$ from the laboratory temperature to $1050{ }^{\circ} \mathrm{C}$ with a $2.5^{\circ} \mathrm{C} \mathrm{min}-1$ temperature gradient. The weights of the studied complexes 1-4, $\mathbf{6}$ and $\mathbf{7}$ (5 was not studied for safety reasons, since it contains the perchlorate anion) were ca. $10 \mathrm{mg} .{ }^{31} \mathrm{P}\left\{{ }^{1} \mathrm{H}\right\}$-NMR spectra of the $\mathrm{CDCl}_{3}$ solutions were measured on a Bruker Avance 300 spectrometer at $300 \mathrm{~K}$ and the spectra were calibrated against $85 \% \mathrm{H}_{3} \mathrm{PO}_{4}$ used as an external reference. $\mathrm{X}$-ray powder diffraction experiments were performed with a PANalytical X'Pert PRO instrument (Co-Ka radiation) equipped with an $\mathrm{X}^{\prime}$ Celerator detector. Samples were placed on a zero-background Si slide and scanned in the $2 \theta$ range of 5-90 in the steps of $0.017^{\circ}$. In situ measurements were realized in the reaction cell XRK900 (Anton Paar). Evaluation was made using HighScore Plus software and PDF-4 database.

\section{Single Crystal X-ray Analysis of the Complexes 4 and $5 \cdot \mathrm{H}_{2} \mathrm{O}$}

A single crystal $\mathrm{X}$-ray measurement was performed on an Xcalibur $^{\mathrm{TM}} 2$ diffractometer (Oxford Diffraction Ltd.) with Sapphire2 CCD detector, and with Mo $\mathrm{K} \alpha$ (Monochromator Enhance, Oxford Diffraction Ltd.) and at $113 \mathrm{~K}(\mathbf{4})$ and $110 \mathrm{~K}$ $\left(5 \cdot \mathrm{H}_{2} \mathrm{O}\right)$. Data collection and reduction were performed by a CrysAlis software [CrysAlis CCD and CrysAlis RED, Version 1.171.33.52, Oxford Diffraction Ltd., Abingdon, England, 2009]. The same software was used for data correction for an absorption effect by the empirical absorption correction using spherical harmonics, implemented in SCALE3 ABSPACK scaling algorithm. Both structures were solved by direct methods using SHELXS-97 software [31] and refined on $F^{2}$ using the full-matrix least-squares procedure (SHELXL-97). Non-hydrogen atoms were refined anisotropically and all hydrogen atoms were located in difference Fourier maps and refined by using the riding model with $\mathrm{C}-\mathrm{H}=$ $0.95,0.98$ and $0.99 \AA$, and $U_{\text {iso }}(\mathrm{H})=1.2 U_{\mathrm{eq}}\left(\mathrm{CH}, \mathrm{CH}_{2}\right)$ or $1.5 U_{\text {eq }}\left(\mathrm{CH}_{3}\right)$, except for those belonging to the crystal water molecule in 5. The perchlorate anion as well as crystal water molecule was refined as disordered over two positions with the occupancy factors $75 \%$ and $25 \%$, and $57 \%$ and $43 \%$, respectively. The crystal data and structure refinements of $\mathbf{4}$ and $\mathbf{5}$ are given in Table 1. The molecular graphics were drawn and the additional structural calculations were interpreted using DIAMOND [32]. Crystallographic data have been deposited with the Cambridge Crystallographic Data Centre, 12 Union Road, Cambridge CB21EZ, UK (Fax: +44-1223-336033; E-Mail: deposit@ccdc.cam.ac.uk). Copies of the data can be obtained free of charge on application to CCDC, as the depository numbers CCDC-766048 (4) and CCDC$766049\left(5 \cdot \mathrm{H}_{2} \mathrm{O}\right)$.

\section{The Catalytic Study}

Graphite $(0.6 \mathrm{~g}$, diameter of particles less than $0.1 \mathrm{~mm}$, ash residue max. $0.2 \%$, mass drying loss max. $0.2 \%$ ) was mixed with an 
acetone solution $(2 \mathrm{~mL})$ of the nickel(II) complex $1,3,5$ or $\mathbf{6}(\mathbf{2}, \mathbf{4}$ and 7 were not studied because of their insufficient solubility in acetone) to give the final nickel concentration of $2.5 \mathrm{mmol} \mathrm{L}^{-1}$. The mixtures were homogenized and dried at room temperature for 24 $\mathrm{h}$. The study of the catalytic influence of these samples on graphite was performed on a Netzsch STA $449 \mathrm{C}$ device with an $\alpha-\mathrm{Al}_{2} \mathrm{O}_{3}$ crucible without a standard $\left(10^{\circ} \mathrm{C} \mathrm{min}^{-1}\right.$ heating rate, sample weight of $5.0 \mathrm{mg}, 100 \mathrm{~mL} \mathrm{~min}^{-1}$ dynamic air atmosphere). The intersection point of the DTG curve tangents represents the initial temperatures of the graphite oxidation. The kinetic parameters were calculated by a direct non-linear regression method [33].

\section{Syntheses of the Nickel(II) Complexes 1-7}

[Ni(BzMedtc) $\left.\left(\mathbf{P P h}_{3}\right) \mathrm{Cl}\right] \quad(1), \quad\left[\mathrm{Ni}(\mathrm{BzMedtc})\left(\mathrm{PPh}_{3}\right) \mathrm{Br}\right] \quad$ (2), [Ni(BzMedtc) $\left.\left(\mathbf{P P h}_{3}\right)\right]$ (3) and [Ni(BzMedtc) $\left.\left(\mathbf{P P h}_{3}\right)(\mathbf{N C S})\right]$ (4): The complex $\mathbf{1}$ was synthesized using the reaction of [Ni(BzMedtc $\left.)_{2}\right](1 \mathrm{mmol})$ and $\left[\mathrm{NiCl}_{2}\left(\mathrm{PPh}_{3}\right)_{2}\right](1 \mathrm{mmol})$. Both starting compounds were suspended in $25 \mathrm{~mL}$ of chloroform $\left(\mathrm{CHCl}_{3}\right)$. The mixture was stirred at room temperature until the reaction components were completely dissolved. The resulting solution was filtered through activated carbon. Diethyl ether was added to the filtrate which was left to stand at laboratory temperature. The precipitate of $\mathbf{1}$ formed in a few days. The product was filtered off, washed with diethyl ether and dried at $40{ }^{\circ} \mathrm{C}$ under an infrared lamp. The complexes $2-\mathbf{4}$ were prepared as described for 1, but $\left[\mathrm{NiBr}_{2}\left(\mathrm{PPh}_{3}\right)_{2}\right]$ (for 2), [ $\left.\mathrm{NiI}_{2}\left(\mathrm{PPh}_{3}\right)_{2}\right]$ (for 3) and $\left[\mathrm{Ni}(\mathrm{NCS})_{2}\left(\mathrm{PPh}_{3}\right)_{2}\right]$ (for 4 ) were used instead of $\left[\mathrm{NiCl}_{2}\left(\mathrm{PPh}_{3}\right)_{2}\right]$. In the case of the complex $\mathbf{4}$, the crystals suitable for a single crystal X-ray analysis were obtained from the mother liquor in two days. [Ni(BzMedtc) $\left(\mathbf{P P h}_{\mathbf{3}}\right) \mathbf{C l}$ ] (1): Yield: $78 \%$. Colour: violet. $\mathrm{C}_{27} \mathrm{H}_{25} \mathrm{NS}_{2} \mathrm{PClNi}\left(\mathrm{M}_{\mathrm{r}}=552.8\right) ; \mathrm{C} 58.7$ (calc. 58.4); H 4.6 (4.6); $\mathrm{N}$ 2.5 (2.4); $\mathrm{S} 11.6$ (11.3); $\mathrm{Cl} 6.4$ (6.5); Ni 10.6 (10.6)\%. [Ni(BzMedtc) $\left(\mathbf{P P h}_{3}\right) \mathbf{B r}$ ] (2): Yield: 90\%. Colour: violet. $\mathrm{C}_{27} \mathrm{H}_{25} \mathrm{NS}_{2} \mathrm{PBrNi}\left(\mathrm{M}_{\mathrm{r}}=597.2\right) ; \mathrm{C} 54.3$ (calc. 54.2); H 4.2 (4.1); $\mathrm{N}$ 2.3 (2.0); $\mathrm{S} 10.7$ (10.3); $\mathrm{Br} 13.4$ (13.1); Ni 9.8 (9.6)\%. [Ni(BzMedtc) $\left(\mathbf{P P h}_{\mathbf{3}}\right)$ ] (3): Yield: 70\%. Colour: dark violet. $\mathrm{C}_{27} \mathrm{H}_{25} \mathrm{NS}_{2} \mathrm{PINi}\left(\mathrm{M}_{\mathrm{r}}=644.2\right)$; C 50.3 (calc. 49.9); H 3.9 (3.9); N 2.2 (2.2); S 10.0 (10.0); I 19.7 (19.3); Ni 9.1 (9.2)\%. [Ni(BzMedtc) $\left(\mathbf{P P h}_{\mathbf{3}}\right)(\mathbf{N C S})$ ] (4): Yield: 82\%. Colour: red. $\mathrm{C}_{28} \mathrm{H}_{25} \mathrm{~N}_{2} \mathrm{~S}_{3} \mathrm{PNi}\left(\mathrm{M}_{\mathrm{r}}=575.4\right) ; \mathrm{C} 58.5$ (calc. 58.9); H 4.4 (4.1); $\mathrm{N}$ 4.9 (4.7); S 16.7 (16.6); Ni 10.2 (10.3)\%.

[Ni(BzMedtc) $\left.\left(\mathbf{P P h}_{3}\right)_{2}\right]_{\mathbf{C l O}}$ (5): $\mathrm{LiClO}_{4} \cdot 3 \mathrm{H}_{2} \mathrm{O} \quad(2 \mathrm{mmol})$ was poured to a suspension of the complex $1(1 \mathrm{mmol})$ and $\mathrm{PPh}_{3}(2$ mmol) in methanol $(25 \mathrm{~mL})$. The reaction mixtures were refluxed for $3 \mathrm{~h}$. The resulting solution was filtered through activated carbon and left to stand at room temperature. The crystals of $\mathbf{5} \cdot \mathrm{H}_{2} \mathrm{O}$ suitable for a single crystal X-ray analysis formed from the mother liquor in a few days. The complex was filtered off, washed with methanol and diethyl ether and dried at $40{ }^{\circ} \mathrm{C}$ under an infrared lamp. Yield: $47 \%$. Colour: pink. $\mathrm{C}_{45} \mathrm{H}_{40} \mathrm{NS}_{2} \mathrm{P}_{2} \mathrm{ClO}_{4} \mathrm{Ni}\left(\mathrm{M}_{\mathrm{r}}=879.0\right)$; C 61.5 (calc. 61.8); H 4.6 (4.3); N 1.6 (1.5); S 7.3 (6.9); Cl 4.2 (4.6); Ni 6.7 (6.8)\%.

[Ni(BzMedtc) $\left.\left(\mathbf{P P h}_{3}\right)_{2}\right] \mathbf{B P h}_{4}(\mathbf{6}): 2 \mathrm{mmol}$ of $\mathrm{Na}\left[\mathrm{BPh}_{4}\right]$ was added to a suspension of $\mathbf{1}(1 \mathrm{mmol})$ and $\mathrm{PPh}_{3}(2 \mathrm{mmol})$ in $25 \mathrm{~mL}$ of methanol. The pink solid appeared during $3 \mathrm{~h}$ of the reaction mixture refluxing. The product was removed by filtration, washed (methanol and diethyl ether) and dried at $40{ }^{\circ} \mathrm{C}$ under an infrared lamp. Yield: $69 \%$. Colour: pink. $\mathrm{C}_{69} \mathrm{H}_{60} \mathrm{NS}_{2} \mathrm{P}_{2} \mathrm{BNi}\left(\mathrm{M}_{\mathrm{r}}=1098.8\right)$; C 75.4 (calc. 75.1); H 5.5 (5.2); N 1.3 (1.5); S 5.8 (5.6); Ni 5.3 (5.7)\%.
[Ni(BzMedtc) $\left.\left(\mathbf{P P h}_{3}\right)_{2}\right] \mathbf{P F}_{6}$ (7): The solutions of $\mathrm{PPh}_{3}(2 \mathrm{mmol} ; 5$ $\mathrm{mL}$ of acetone) and $\mathrm{K}\left[\mathrm{PF}_{6}\right](1 \mathrm{mmol} ; 7 \mathrm{~mL}$ of acetone $)$ were separately added to a solution of $\mathbf{1}$ ( $1 \mathrm{mmol} ; 5 \mathrm{~mL}$ of chloroform). The reaction mixture was refluxed for a period of $4 \mathrm{~h}$ and after that it was filtered through activated carbon. Diethyl ether was added to the filtrate, which caused the formation of the precipitate. The solid was filtered off, washed with diethyl ether and dried at $40{ }^{\circ} \mathrm{C}$ under an infrared lamp. Yield: 54\%. Colour: red. $\mathrm{C}_{45} \mathrm{H}_{40} \mathrm{NS}_{2} \mathrm{P}_{3} \mathrm{~F}_{6} \mathrm{Ni}\left(\mathrm{M}_{\mathrm{r}}=\right.$ 924.5); C 58.5 (calc. 58.8); H 4.4 (4.6); N 1.6 (1.9); S 6.9 (6.5); Ni $6.3(6.7) \%$.

\section{Acknowledgement}

This work was financially supported by The Ministry of Education, Youth and Sports of the Czech Republic (a grant no. MSM6198959218). The authors also thank Assoc. Prof. Zdeněk Šindelár̆ for magnetic susceptibility measurements, Dr. Jan Filip for X-Ray powder diffraction experiments.

\section{References}

[1] G. Hogarth, Prog. Inorg. Chem. 2005, 53, 71-561

[2] P. J. Nieuwenhuizen, A. W. Ehlers, J. G. Haasnoot, S. R. Janse, J. Reedijk, E. J. Baerends, J. Am. Chem. Soc. 1999, $121,163-168$

[3] S. L. Cao, Y. P. Feng, Y. Y. Jiang, S. Y. Liu, G. Y. Ding, R. T. Li, Bioorg. Med. Chem. 2005, 15, 1915-1917

[4] C. Gerhauser, M. You, J. Liu, R. M. Moriarty, M. Hawthorne, R. G. Metha, R. C. Moon, J. M. Pezzuto, Cancer Res. 1997, $57,272-278$

[5] S. Hidaka, T. Funakoshi, H. Shimada, M. Tsuruoka, S. Kojima, J. App. Toxicol. 1995, 15, 167-273

[6] C. Marzano, F. Bettio, F. Baccichetti, A. Trevisan, L. Giovagnini, D. Fregona, Chem. Biol. Interact. 2004, 148, 3748

[7] L. Ronconi, C. Marzano, P. Zanello, M. Corsini, G. Miolo, C. Macca, A. Trevisan, D. Fregona, J. Med. Chem. 2006, 49, $1648-1657$

[8] D. C. Menezes, F. T. Vieira, G. M. de Lima, A. O. Porto, M. E. Cortés, J. D. Ardisson, T. E. Albrecht Schmitt, Eur. J. Med. Chem. 2005, 40, 1277-1282

[9] F. A. Allen, Acta Crystallogr., Sect. B: Struct. Sci. 2002, 58, 380-388

[10] B. Arul Prakasam, K. Ramalingam, R. Baskaran, G. Bocelli, A. Cantoni, Polyhedron 2007, 26, 1133-1138

[11] M. R. L. Oliveira, J. Amim Jr., I. A. Soares, V. M. De Bellis, C. A. de Simone, C. Novais, S. Guilardi, Polyhedron 2008, 27, 727-733

[12] R. Pastorek, J. Kameníček, J. Husárek, V. Slovák, M. Pavlíček, J. Coord. Chem. 2007, 60, 485-494

[13] Z. Trávníček, R. Pastorek, V. Slovák, Polyhedron 2008, 27, 411-419

[14] X. Gong, Z. Guo, Z. Wang, Combust. Flame 2010, 157, 351356

[15] Z. H. Wu, L. Xu, Z. Z. Wang, Z. R. Zhang, Fuel 2008, 77, 891-893

[16] J. Carrazza, W. T. Tysoe, H. Heinemann, G. A. Somorjai, J. Catal. 1985, 96, 234-241

[17] W. J. Lee, S. D. Kim, Fuel 1995, 74, 1387-1393

[18] R. Pastorek, J. Kameníček, H. Vrbová, V. Slovák, M. Pavlíček, J. Coord. Chem. 2006, 59, 437-444 
[19] R. Pastorek, J. Kameníček, B. Cvek, V. Slovák, M. Pavlíček, J. Coord. Chem. 2006, 59, 911-919

[20] W. J. Geary, Coord. Chem. Rev. 1971, 7, 81-122

[21] C. A. Tsipis, D. P. Kessissoglou, G. A. Katsoulos, Chim. Chron., New Series 1985, 14, 195

[22] S. V. Larionov, L. A. Patrina, I. M. Oglezneva, E. M. Uskov, Koord. Chim. 1984, 10, 92-99

[23] R. P. Scholer, E. A. Merbach, Inorg. Chim. Acta 1975, 15, $15-20$

[24] L. Ballester, A. Gutierrez, M. F. Perpinan, C. Ruiz-Valero, Polyhedron 1996, 15, 1103-1112

[25] A. B. P. Lever in Inorganic Electronic Spectroscopy (2nd edit), Elsevier, Amsterdam, 1984, p. 534

[26] C. A. Tsipis, D. P. Kessissoglou, G. E. Manoussakis, Inorg. Chim. Acta 1982, 65, L137-L141

[27] C. A. Tsipis, I. E. Meleziadis, D. P. Kessissoglou, G. A. Katsoulos, Inorg. Chim. Acta 1984, 90, L19-L22

[28] D. R. Lide (Ed.) in Handbook of Chemistry and Physics (73rd edit), CRC Press, Boca Raton, 1992

[29] F. Březina, E. Benátská, J. Thermal. Anal. 1981, 22, 75-79

[30] Gmelins Handbuch der Anorganischen Chemie, Nickel, Teil C, Lief. 2, Verlag Chemie, GmbH, Weinheim, 1969, p. 1043

[31] G. M. Sheldrick, Acta Cryst. 2008, A64, 112-122

[32] K. Brandenburg, DIAMOND, Release 3.1f, Crystal Impact GbR, Bonn, Germany, 2006

[33] V. Slovák, Thermochim. Acta 2001, 372, 175-182

Received: ((will be filled in by the editorial staff)) Published online: ((will be filled in by the editorial staff)) 


\section{Entry for the Table of Contents}

Seven nickel(II) $N$-benzyl- $N$-methyldithiocarbamato (BzMedtc) complexes were prepared and characterized. The structures of $\left[\mathrm{Ni}(\mathrm{BzMedtc})\left(\mathrm{PPh}_{3}\right)(\mathrm{NCS})\right](\mathbf{4})$ and $\left[\mathrm{Ni}(\mathrm{BzMedtc})\left(\mathrm{PPh}_{3}\right)_{2}\right] \mathrm{ClO}_{4} \cdot \mathrm{H}_{2} \mathrm{O}\left(\mathbf{5} \cdot \mathrm{H}_{2} \mathrm{O}\right)$ were determined by a single crystal X-ray analysis, which showed the $\mathrm{Ni}$ (II) centre as four-coordinated in a distorted square-planar geometry. The positive catalytic effect of the complexes $\mathbf{1}, \mathbf{3}, \mathbf{5}$, and $\mathbf{6}$ on the graphite oxidation was determined. The start temperatures of the oxidation of the complexes were by about $60-100{ }^{\circ} \mathrm{C}$ lower in comparison with pure graphite.

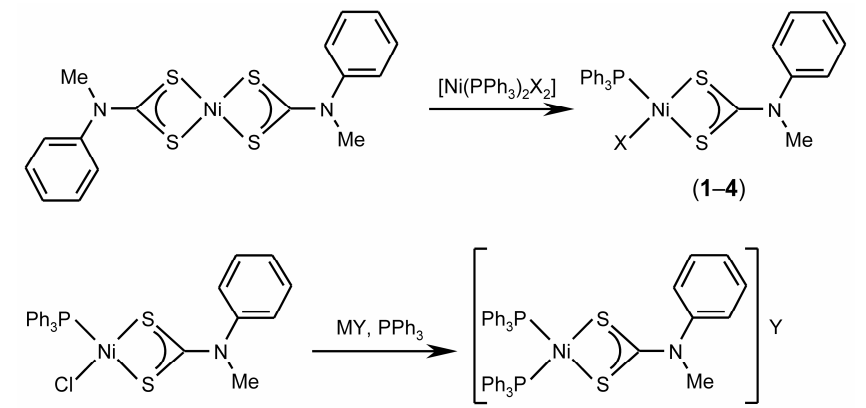

(1)

$\mathrm{X}=\mathrm{Cl}^{-}$(complex 1), $\mathrm{Br}^{-}(2), \mathrm{I}^{-}(3), \mathrm{NCS}^{-}(4)$ $\mathrm{Y}=\mathrm{ClO}_{4}^{-}(\mathbf{5}), \mathrm{BPh}_{4}^{-}(\mathbf{6}), \mathrm{PF}_{6}^{-}(\mathbf{7})$

Zdeněk Trávníček, ${ }^{*[a]}$ Richard Pastorek, ${ }^{[\mathrm{a}]}$ Pavel Štarha, ${ }^{[\mathrm{a}]}$ Igor Popa, ${ }^{[a]}$ and Václav Slovák ${ }^{[\mathrm{b}]}$

* Corresponding Author

Fax: +420585 634357

E-Mail: zdenek.travnicek@upol.cz

Nickel(II) $N$-benzyl- $N$-methyldithiocarbamato complexes as precursors for the preparation of graphite oxidation accelerators 


\title{
Nickel(II) $N$-benzyl- $N$-methyldithiocarbamato complexes as precursors for the preparation of graphite oxidation accelerators
}

\author{
Zdeněk Trávníček, ${ }^{*[a]}$ Richard Pastorek, ${ }^{[a]}$ Pavel Štarha, ${ }^{[a]}$ Igor Popa, ${ }^{[a]}$ and Václav Slovák ${ }^{[b]}$
}

Keywords: Nickel(II)complex; Dithiocarbamato ligand; Crystal structure; Graphite oxidation accelerator.

\begin{abstract}
The nickel(II) $N$-benzyl- $N$-methyldithiocarbamato (BzMedtc) complexes [Ni(BzMedtc) $\left.\left(\mathrm{PPh}_{3}\right) \mathrm{Cl}\right](\mathbf{1})$, [Ni(BzMedtc) $\left.\left(\mathrm{PPh}_{3}\right) \mathrm{Br}\right](\mathbf{2})$, $\left[\mathrm{Ni}(\mathrm{BzMedtc})\left(\mathrm{PPh}_{3}\right) \mathrm{I}\right](\mathbf{3})$ and $\left[\mathrm{Ni}(\mathrm{BzMedtc})\left(\mathrm{PPh}_{3}\right)(\mathrm{NCS})\right](\mathbf{4})$ were synthesized using the reaction of $\left[\mathrm{Ni}(\mathrm{BzMedtc})_{2}\right]$ and $\left[\mathrm{NiX}_{2}\left(\mathrm{PPh}_{3}\right)_{2}\right]$, where $\mathrm{X}=\mathrm{Cl}, \mathrm{Br}$, I and NCS. Subsequently, the complex 1 was used for the preparation of $\left[\mathrm{Ni}(\mathrm{BzMedtc})\left(\mathrm{PPh}_{3}\right)_{2}\right] \mathrm{ClO}_{4}(\mathbf{5}),\left[\mathrm{Ni}(\mathrm{BzMedtc})\left(\mathrm{PPh}_{3}\right)_{2}\right] \mathrm{BPh}_{4}(\mathbf{6})$ and $\left[\mathrm{Ni}(\mathrm{BzMedtc})\left(\mathrm{PPh}_{3}\right)_{2}\right] \mathrm{PF}_{6}(\mathbf{7})$. The obtained complexes 1-7 were characterized by elemental analysis, thermal analysis and spectroscopic methods (IR, UV-Vis, ${ }^{31} \mathrm{P}\left\{{ }^{1} \mathrm{H}\right\}$-NMR). The results of the magnetochemical and molar conductivity measurements proved the complexes as diamagnetic non-electrolytes (1-4) or 1:1 electrolytes (5-7).
\end{abstract}

* Corresponding Author

Fax: +420585634 357

E-Mail: zdenek.travnicek@upol.cz

[a] Department of Inorganic Chemistry

Faculty of Science, Palacký University

Tř. 17. listopadu 12, CZ-771 46 Olomouc, Czech Republic

[b] Department of Chemistry

Faculty of Science, University of Ostrava

30. dubna 22, CZ-701 03 Ostrava, Czech Republic

Supporting information for this article is available on the

WWW under http://dx.doi.org/10.1002/zaac.201000xxx or from the author.

\section{Introduction}

Many compounds involving the dithiocarbamate (dtc) moiety were reported up to now in connection with their applications. These compounds have been found to be useful as fungicides [1] or accelerators of vulcanization [2]. However, the spectrum of potential use of these compounds may be also broadened on the field of in vitro anticancer activity as can be demonstrated by the following examples. The 4(3H)-quinazolinone derivatives with dithiocarbamate side chains, such as (3,4-dihydro-2-methyl-4-oxoquinazolin6-yl)-methyl-[4-(4-fluorophenyl)piperazine]-1-carbodithioate, showed promising in vitro anticancer activity $\left(\mathrm{IC}_{50}=0.5\right.$ $\mu \mathrm{M}$ ) against human myelogenous leukaemia cell line (K562) [3]. Another dithiocarbamate derivative, 4-methylsulfinyl-1(S-methyldithiocarbamyl)-butane (sulforamate), serves as a bearer of cancer chemopreventive effect [4]. The efficient protection of $N$-benzyl- $D$-glucamine-dithiocarbamate against cisplatin-induced nephrotoxicity (it is able to chelate platinum and thus to decrease the possibility of its reactions with sulphur-containing renal proteins or enzymes) has also been reported recently [5].

\begin{abstract}
The molecular structures of $\mathbf{4}$ and $\mathbf{5} \cdot \mathrm{H}_{2} \mathrm{O}$ were determined by a single crystal $\mathrm{X}$-ray analysis. In all cases, the $\mathrm{Ni}$ (II) atom is four-coordinated in a distorted square-planar arrangement with the $\mathrm{S}_{2} \mathrm{PX}$, and $\mathrm{S}_{2} \mathrm{P}_{2}$ donor set, respectively. The catalytic influence of selected complexes $\mathbf{1}, \mathbf{3}, \mathbf{5}$, and $\mathbf{6}$ on graphite oxidation was studied. The results clearly indicated that the presence of the products of thermal degradation processes of the mentioned complexes have impact on the course of graphite oxidation. A decrease in the oxidation start temperatures by about $60-100{ }^{\circ} \mathrm{C}$ was observed in the cases of all the tested complexes in comparison with pure graphite.
\end{abstract}

Several thousands of transition metal complexes involving the dithiocarbamate moiety have been prepared and reported to date and some of them are very promising from the biological activity point of view. The $\mathrm{Pt}(\mathrm{II})$ complex of the [Pt(esdt)(py)Cl] composition, where esdt = ethylsarcosinedithiocarbamate and py = pyridine, is highly cytotoxic against several human cancer cell lines, and moreover, this substance was not found as nephrotoxic, contrary to cisplatin [6]. $\left[\mathrm{Au}(\mathrm{dmdt}) \mathrm{X}_{2}\right]$ and $\left[\mathrm{Au}(\mathrm{esdt}) \mathrm{X}_{2}\right]$ are the representatives of non-platinum complex with the promising anticancer activity, which is even higher compared to cisplatin; $\mathrm{dmdt}=N, N^{\prime}-$ dimethyldithiocarbamate, $\mathrm{X}=\mathrm{Cl}$ or $\mathrm{Br}$ [7]. The antifungal activity, well-known for dithiocarbamate derivatives, was proved for tin(IV) complexes with pyrrolidinedithiocarbamate [8].

Nickel is known as a suitable transition metal for the preparation of complexes and it is not surprising that over three thousand compounds (SciFinder, 2010) and 163 X-ray structures (Crystallographic Structural Database, CSD, ver. 5.30, September 2009 update [9]) involving an $\mathrm{NiS}_{2} \mathrm{CN}$ motif have been reported to date. Among these compounds, the nickel(II) complexes involving the $\mathrm{NiPN}\left(\mathrm{S}_{2} \mathrm{CN}\right)$ or $\mathrm{NiP}_{2}\left(\mathrm{~S}_{2} \mathrm{CN}\right)$ moiety, such as [Ni(4-MePzdtc $\left.)\left(\mathrm{PPh}_{3}\right)(\mathrm{NCS})\right]$ [10], and [Ni(MeSdtc)(dppe)] [11], respectively, have been described in the literature; 4-MePzdtc $=4$-methylpiperazinedithicarbamate anion, $\mathrm{PPh}_{3}=$ triphenylphosphine, $\mathrm{MeSdtc}=$ $N$-methyl- $N$-sulfonyldithiocarbamate, dppe $=1,2$-bis (diphenylphosphine)ethane. However, no nickel complexes containing the $N$-benzyl- $N$-methyldithiocarbamate anion (BzMedtc) within the mentioned moieties, have been reported to date. 
The presented series of compounds follows a great number of nickel dithicarbamato complexes previously prepared at our department [see ref. 12,13 and the references cited therein]. In this paper, we deal with seven nickel(II) complexes, whose structures, according to the literature research, for the first time involves a combination of the BzMedtc and $\mathrm{PPh}_{3}$ ligands. The complexes $\left[\mathrm{Ni}(\mathrm{BzMedtc})\left(\mathrm{PPh}_{3}\right) \mathrm{X}\right] \quad(\mathbf{1}-\mathbf{4})$ were synthesized from $\left[\mathrm{Ni}(\mathrm{BzMedtc})_{2}\right]$, using its reaction with $\left[\mathrm{NiX}_{2}\left(\mathrm{PPh}_{3}\right)_{2}\right]$, where $\mathrm{X}$ stands for $\mathrm{Cl}^{-}$(for the complex 1), $\mathrm{Br}^{-}(\mathbf{2}), \mathrm{I}^{-}(\mathbf{3})$ and $\mathrm{NCS}^{-}(\mathbf{4})$. The $\left[\mathrm{Ni}(\mathrm{BzMedtc})\left(\mathrm{PPh}_{3}\right)_{2}\right] \mathrm{Y}$ complexes $(\mathrm{Y}=$ $\mathrm{ClO}_{4}^{-}$for $5, \mathrm{BPh}_{4}^{-}$for 6 and $\mathrm{PF}_{6}^{-}$for 7) were prepared by the reaction of complex $\mathbf{1}$ with the appropriate alkaline salt and triphenylphosphine (see Scheme 1). The products were characterized by various physical methods including ${ }^{31} \mathrm{P}\left\{{ }^{1} \mathrm{H}\right\}-\mathrm{NMR}$ spectroscopy. The X-ray structures of the representatives of both types of complexes, i.e. $\left[\mathrm{Ni}(\mathrm{BzMedtc})\left(\mathrm{PPh}_{3}\right)(\mathrm{NCS})\right] \quad(4)$ and [Ni(BzMedtc)$\left.\left(\mathrm{PPh}_{3}\right)_{2}\right] \mathrm{ClO}_{4} \cdot \mathrm{H}_{2} \mathrm{O}\left(\mathbf{5} \cdot \mathrm{H}_{2} \mathrm{O}\right)$, were determined by a single crystal X-ray analysis. The geometry of these compounds is square-planar with the $\mathrm{NiS}_{2} \mathrm{PN}$ (4) and $\mathrm{NiS}_{2} \mathrm{P}_{2}\left(\mathbf{5} \cdot \mathrm{H}_{2} \mathrm{O}\right)$ donor sets.

This work also describes the effect of the nickel(II) dithiocarbamates on the oxidation of graphite as a model study of the coal combustion. As it is commonly known, the ignition temperature of the coal combustion is one of the most important properties influencing many industrial processes. This stage can be affected by the presence of both natural and artificial impurities [14,15]. Formerly, several papers reported simple nickel(II) compounds, such as $\mathrm{NiO}$ (mixed with $\mathrm{KOH}$ ) or $\mathrm{Ni}\left(\mathrm{NO}_{3}\right)_{2}$ (mixed with $\mathrm{K}_{2} \mathrm{SO}_{4}$ ), as the substances accelerating graphite oxidation [16,17]. Few years ago, we decided to study the influence of the nickel(II, IV) dithiocarbamato complexes [see 13,18,19 and references cited therein] on the course of graphite oxidation. It was found that the presence of these complexes causes the ignition temperature decrease. Similar results were obtained also for the tested complexes $\mathbf{1}, \mathbf{3}, \mathbf{5}$, and $\mathbf{6}$, which were chosen as representatives of the presented compounds, as it is discussed in more detail within the framework of this paper.

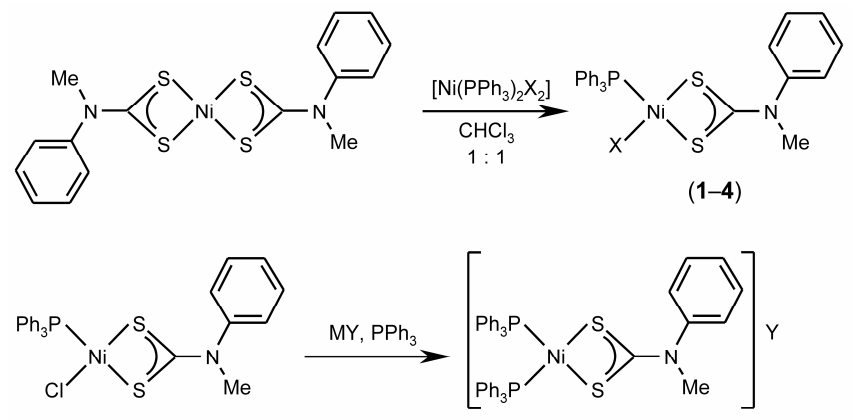

(1)

(5-7)

Scheme 1. Schematic representation of the synthetic procedures applied for the preparation of the nickel(II) complexes 1-7; X = $\mathrm{Cl}^{-}(\mathbf{1}), \mathrm{Br}^{-}(\mathbf{2}), \mathrm{I}^{-}$(3) and $\mathrm{NCS}^{-}(\mathbf{4}), \mathrm{MY}=\mathrm{LiClO}_{4} \cdot 3 \mathrm{H}_{2} \mathrm{O}(\mathbf{5})$, $\mathrm{Na}\left[\mathrm{BPh}_{4}\right](\mathbf{6})$ and $\left.\mathrm{K}_{2} \mathrm{PF}_{6}\right](\mathbf{7})$.

\section{Results and Discussion}

The nickel(II) complexes 1-7 were prepared according to the synthetic strategies depicted in Scheme 1. The obtained molar conductivity values (Table 1 ) indicate that complexes 1-4 dissolved in acetone behave as non-electrolytes [20], which indirectly proved the coordination of the $\mathrm{Cl}^{-}(\mathbf{1}), \mathrm{Br}^{-}$ (2), $\mathrm{I}^{-}$(3) and $\mathrm{NCS}^{-}$(4) anions to the $\mathrm{Ni}(\mathrm{II})$ atom. On the other hand, the molar conductivity values of the remaining complexes proved the ionic nature (1:1 electrolyte type) in acetone $(5)$ or DMF $(6,7)$ solutions, which means that the $\mathrm{ClO}_{4}^{-}{ }^{-}(5), \mathrm{BPh}_{4}^{-}(\mathbf{6})$ and $\mathrm{PF}_{6}^{-}(7)$ anions are situated outside of the inner coordination sphere within the structure of the discussed complexes. The results of the room temperature magnetochemical measurements determined the prepared compounds to be diamagnetic, and thus, suggested on square-planar geometries in the vicinity of the central atom.

Table 1: The results of molar conductivity measurements, IR, UV-Vis and ${ }^{31} \mathrm{P}\{\mathrm{H}\}$-NMR spectroscopy of the complexes 1-7

\begin{tabular}{|c|c|c|c|c|c|c|}
\hline & $\lambda_{\mathrm{M}}^{\mathrm{a}}$ & $\begin{array}{l}\text { IR }(\mathrm{cm} \\
v(\mathrm{C} \cdots \mathrm{S}\end{array}$ & $\begin{array}{l}-1)^{b} \\
v\left(C^{-\cdots} N\right)\end{array}$ & other & $\begin{array}{l}\text { UV-Vis } \\
\left(\mathrm{cm}^{-1}\right)^{\mathrm{c}}\end{array}$ & $\begin{array}{l}{ }^{31} \mathrm{P}\{\mathrm{H}\}-\mathrm{NMR} \\
\delta^{\mathrm{d}}(\mathrm{ppm})\end{array}$ \\
\hline 1 & 2.2 & $990 \mathrm{~m}$ & $1510 \mathrm{~m}$ & & $\begin{array}{l}19200 \\
25200 \\
29000\end{array}$ & $21.1 \mathrm{~s}$ \\
\hline 2 & 2.1 & $996 \mathrm{~m}$ & $1520 \mathrm{~m}$ & & $\begin{array}{l}18900 \\
25000 \\
29000\end{array}$ & $24.8 \mathrm{~s}$ \\
\hline 3 & 9.3 & $998 \mathrm{~m}$ & $1520 \mathrm{~m}$ & & $\begin{array}{l}18400 \\
31400\end{array}$ & $31.6 \mathrm{~s}$ \\
\hline 4 & 1.7 & $996 \mathrm{~m}$ & $1528 \mathrm{~m}$ & $\begin{array}{l}840 \mathrm{~m} v(\mathrm{C}-\mathrm{S}) \\
2092 \mathrm{~s} v(\mathrm{C} \equiv \mathrm{N})\end{array}$ & $\begin{array}{l}20400 \\
29000\end{array}$ & $22.8 \mathrm{~s}$ \\
\hline 5 & 99.0 & $996 w$ & $1542 \mathrm{~m}$ & $\begin{array}{l}622 \mathrm{~m} v_{4}\left(\mathrm{ClO}_{4}^{-}\right) \\
1088 \mathrm{~s} v_{3}\left(\mathrm{ClO}_{4}^{-}\right)\end{array}$ & $\begin{array}{l}19900 \\
31000\end{array}$ & $32.0 \mathrm{~s}$ \\
\hline 6 & 77.3 & $990 \mathrm{~m}$ & $1536 \mathrm{~s}$ & & $\begin{array}{l}20700 \\
30900\end{array}$ & $32.1 \mathrm{~s}$ \\
\hline 7 & 66.9 & $996 \mathrm{~m}$ & $1540 \mathrm{~m}$ & $836 \mathrm{~m} v_{4}\left(\mathrm{PF}_{6}^{-}\right)$ & $\begin{array}{l}19800 \\
29300 \\
\end{array}$ & $\begin{array}{l}32.0 \mathrm{~s}, \\
-143.6 \mathrm{sp}\end{array}$ \\
\hline
\end{tabular}

[a] $\mathrm{S} \mathrm{cm}^{2} \mathrm{~mol}^{-1}\left(10^{-3} \mathrm{M}\right.$ acetone solutions for $\mathbf{1 - 5}$ and $5 \times 10^{-4} \mathrm{M}$ DMF solutions for 6 and 7); [b] $\mathrm{KBr}$ pellets $(\mathrm{w}=$ weak, $\mathrm{m}=$ middle, $\mathrm{s}=$ strong); [c] nujol technique; [d] $\mathrm{CDCl}_{3}$ solutions $(\mathrm{s}=$ singlet, $\mathrm{sp}=$ septuplet)

\section{Spectroscopic Characterization}

The $\mathrm{PPh}_{3}$ signals in the ${ }^{31} \mathrm{P}\left\{{ }^{1} \mathrm{H}\right\}-\mathrm{NMR}$ spectra of the $\mathrm{CDCl}_{3}$ solutions of 1-7 were found in the range of 21.1$32.1 \mathrm{ppm}$ (Table 1). These values differ significantly from that of $-4.52 \mathrm{ppm}$ determined for the free $\mathrm{PPh}_{3}$ molecule, which is caused by electron density redistribution from phosphorus towards the $\mathrm{Ni}$ (II) centre as a consequence of $\mathrm{PPh}_{3}$ coordination. The spectrum of 7 contains a septuplet at $-143.6 \mathrm{ppm}$ assignable to the $\mathrm{PF}_{6}{ }^{-}$anion. It should be noted that the chemical shift values of the complexes 1-4 increased in the order $\left[\mathrm{Ni}(\mathrm{Cl})(\mathrm{BzMedtc})\left(\mathrm{PPh}_{3}\right)\right]$ (1) < $\left[\mathrm{Ni}(\mathrm{NCS})(\mathrm{BzMedtc})\left(\mathrm{PPh}_{3}\right)\right](4)<\left[\mathrm{Ni}(\mathrm{Br})(\mathrm{BzMedtc})\left(\mathrm{PPh}_{3}\right)\right]$ (2) $<\left[\mathrm{Ni}(\mathrm{I})(\right.$ BzMedtc $\left.)\left(\mathrm{PPh}_{3}\right)\right](3)$, which agrees with the results reported for the nickel(II) complexes with $N$-benzyl$N$-butyldithiocarbamate [12].

The maxima observed in the IR spectra of the nickel(II) complexes 1-7 at 990-998 $\mathrm{cm}^{-1}$, and 1510-1542 $\mathrm{cm}^{-1}$ (see

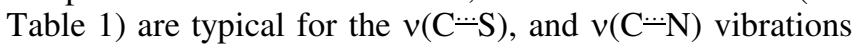
of the dithiocarbamate moiety, respectively $[21,22]$. The 
peak of the $v(\mathrm{C} \cdots \mathrm{S})$ stretching vibration is not split, which supports the bidentate coordination of the BzMedtc anion. The peaks of the $v(\mathrm{C} \equiv \mathrm{N})$ and $v(\mathrm{C}-\mathrm{S})$ vibrations of the $\mathrm{NCS}^{-}$ anion were observed in the IR spectrum of 4 . The ionic nature of the perchlorate anion in the complex $\mathbf{5}$, can be supported by two undivided peaks at 622 and $1088 \mathrm{~cm}^{-1}$ [23]. The same conclusion can be made for the complex 7 , whose IR spectrum contains the non-split peak at $836 \mathrm{~cm}^{-1}$ assignable to $v\left(\mathrm{PF}_{6}^{-}\right)$, which again indicates its ionic nature [24].

Table 2. Crystal data and structure refinements for [Ni(NCS)(BzMedtc) $\left.\left(\mathrm{PPh}_{3}\right)\right] \quad$ (4) $\left[\mathrm{Ni}(\right.$ BzMedtc $\left.)\left(\mathrm{PPh}_{3}\right)_{2}\right] \mathrm{ClO}_{4} \cdot \mathrm{H}_{2} \mathrm{O}\left(\mathbf{5} \cdot \mathrm{H}_{2} \mathrm{O}\right)$

\begin{tabular}{|c|c|c|}
\hline Compound & 4 & $5 \cdot \mathrm{H}_{2} \mathrm{O}$ \\
\hline Empirical formula & \multicolumn{2}{|c|}{$\mathrm{C}_{28} \mathrm{H}_{25} \mathrm{~N}_{2} \mathrm{NiPS}_{3} \mathrm{C}_{45} \mathrm{H}_{42} \mathrm{ClNNiO}_{5} \mathrm{P}_{2} \mathrm{~S}_{2}$} \\
\hline Formula weight & 575.36 & 897.02 \\
\hline Temperature (K) & $113(2)$ & $110(2)$ \\
\hline Wavelength $(\AA)$ & 0.71073 & 0.71073 \\
\hline Crystal system & Monoclinic & Triclinic \\
\hline Space group & $P 2_{1} / n$ & $P-1$ \\
\hline$a(\AA)$ & $13.6177(3)$ & $11.47995(13)$ \\
\hline$b(\AA)$ & $10.3556(2)$ & $13.24049(16)$ \\
\hline$c(\AA)$ & 19.1287(4) & $15.02884(19)$ \\
\hline$\alpha\left(^{\circ}\right)$ & 90 & $70.3319(11)$ \\
\hline$\beta\left(^{\circ}\right)$ & $92.4015(18)$ & $84.5683(10)$ \\
\hline$\gamma\left({ }^{\circ}\right)$ & 90 & $87.3995(9)$ \\
\hline$V\left(\AA^{3}\right)$ & 2695.6(9) & 2141.23(4) \\
\hline$Z, D_{\text {calc }}\left(\mathrm{g} \mathrm{cm}^{-3}\right)$ & $4,1.418$ & $2,1.391$ \\
\hline Absorption coefficient & $1.032 \mathrm{~mm}^{-1}$ & $0.734 \mathrm{~mm}^{-1}$ \\
\hline Crystal size (mm) & \multicolumn{2}{|c|}{$0.30 \times 0.25 \times 0.250 .40 \times 0.35 \times 0.30$} \\
\hline$F(000)$ & 1192 & 932 \\
\hline$\theta$ range for data collection $\left({ }^{\circ}\right)$ & $2.90 \leq \theta \leq 25.00$ & $3.03 \leq \theta \leq 25.00$ \\
\hline \multirow[t]{3}{*}{ Index ranges $(h, k, l)$} & $-16 \leq h \leq 16$ & $-13 \leq h \leq 13$ \\
\hline & $-9 \leq k \leq 12$ & $-15 \leq k \leq 15$ \\
\hline & $-22 \leq l \leq 22$ & $-17 \leq l \leq 15$ \\
\hline Reflections collected/unique & $22656 / 4743$ & $18531 / 7526$ \\
\hline$\left(R_{\text {int }}\right)$ & $(0.0246)$ & $(0.0108)$ \\
\hline Max./min. transmission & $0.7825 / 0.7471$ & $0.8099 / 0.7578$ \\
\hline Data/restraints/parameters & $4743 / 0 / 317$ & $7526 / 0 / 553$ \\
\hline Goodness-of-fit on $F^{2}$ & 1.065 & 1.039 \\
\hline Final $R$ indices $[I>2 \sigma(I)]$ & $\begin{array}{l}R_{1}=0.0282, \\
\mathrm{w} R_{2}=0.0673\end{array}$ & $\begin{array}{l}R_{1}=0.0342, \\
\mathrm{w} R_{2}=0.1009\end{array}$ \\
\hline$R$ indices (all data) & $\begin{array}{l}R_{1}=0.0366 \\
\mathrm{w} R_{2}=0.0692\end{array}$ & $\begin{array}{l}R_{1}=0.0388, \\
\mathrm{w} R_{2}=0.1031\end{array}$ \\
\hline Largest peak/hole $\left(\mathrm{e} \AA^{-3}\right)$ & $0.344 /-0.212$ & 1.343 and -0.611 \\
\hline
\end{tabular}

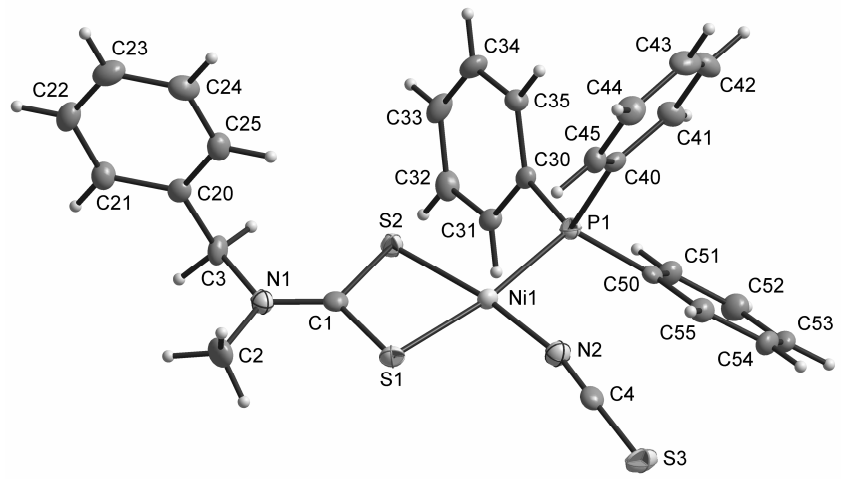

Figure 1. The molecular structure of $\left[\mathrm{Ni}(\mathrm{BzMedtc})\left(\mathrm{PPh}_{3}\right)(\mathrm{NCS})\right]$ complex (4) with non-hydrogen atoms drawn as thermal ellipsoids at the $50 \%$ probability level.

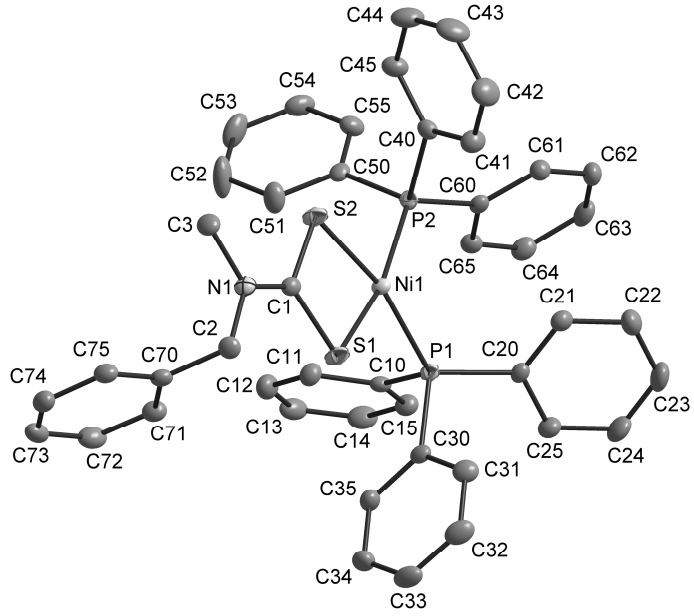

Figure 2. The molecular structure of atoms drawn as thermal ellipsoids at the $50 \%$ probability level. The hydrogen atoms, perchlorate anion and water molecule of crystallization were omitted for clarity.

Diffuse-reflectance electronic spectra of the prepared complexes 1-7 support the assumption of the square-planar geometry in the vicinity of the central $\mathrm{Ni}(\mathrm{II})$ atom. Absorption maxima at the $18400-20700 \mathrm{~cm}^{-1}$ region may be attributed to the ${ }^{1} \mathrm{~A}_{1 \mathrm{~g}} \rightarrow{ }^{1} \mathrm{~B}_{1 \mathrm{~g}}$ transition of the squareplanar nickel(II) complexes [25,26]. The next maxima, also assignable to the $d$ - $d$ transitions, were found for the complexes $1\left(25200 \mathrm{~cm}^{-1}\right)$ and $\mathbf{2}\left(25000 \mathrm{~cm}^{-1}\right)$. The maxima above $29000 \mathrm{~cm}^{-1}$ are probably connected with the intraligand charge-transfer transitions in the $\mathrm{S}_{2} \mathrm{CN}$ moiety [27].

\section{$X$-ray Structure of $\left[\mathrm{Ni}(\mathrm{NCS})(\mathrm{BzMedtc})\left(\mathrm{PPh}_{3}\right)\right](4)$ and $\left[\mathrm{Ni}(\mathrm{Bz} \mathrm{Medtc})\left(\mathrm{PPh}_{3}\right)_{2}\right] \mathrm{ClO}_{4} \cdot \mathrm{H}_{2} \mathrm{O}\left(5 \cdot \mathrm{H}_{2} \mathrm{O}\right)$}

The X-ray structure of the title complexes 4 (Figure 1) and $\mathbf{5} \cdot \mathrm{H}_{2} \mathrm{O}$ (Figure 2 ) was determined by a single crystal X-ray analysis. The crystal data and structure refinements are given in Table 2, while the selected bond lengths and angles are summarized in Table 3.

The central Ni(II) ion of the complex 4 (Figure 1) is fourcoordinated by $\mathrm{PPh}_{3}$, the isothiocyanate anion, and the bidentate-coordinated $N$-benzyl- $N$-methyldithiocarbamate anion (BzMedtc). The atoms of a $\mathrm{NiS}_{2} \mathrm{NP}$ chromophore are arranged in the distorted square-planar geometry around the metal centre (Table 3 ). The Ni-S bond lengths of the title complex correlate well with the mean value of $2.204 \AA$ (2.155-2.258 $\AA$ interval) determined for this band for the 116 square-planar nickel complexes involving bidentate-coordinated dithiocarbamato S-donor ligands, which have been up to now deposited in the Cambridge Structural Database (CSD) [9].

The well-known delocalization of $\pi$-electron density within the $\mathrm{S}_{2} \mathrm{CN}$ moiety of the dithiocarbamate anion was observed for 4 , since the $\mathrm{C}-\mathrm{N}$ and $\mathrm{C}-\mathrm{S}$ bond lengths of the 
studied compound (Table 2) were found to be significantly shorter compared to the single $\mathrm{C}-\mathrm{N}(1.47 \AA)$ and $\mathrm{C}-\mathrm{S}(1.81$ $\AA$ ) $\sigma$-bond lengths [28]. Further, the $\mathrm{C}-\mathrm{S}$ and $\mathrm{C}-\mathrm{N}$ bond length values of BzMedtc are comparable with those of the transition metal (TM) complexes involving the (TM) $\mathrm{S}_{2} \mathrm{CNR}_{2}$ moiety and deposited within the CSD, which equal $1.717 \AA$, and $1.326 \AA$, respectively.

The $\mathrm{S} 1$ atom is the most deviated one [0.0454(5) $\AA$ ] from the plane created through the Ni1, S1, S2, P1 and N2 atoms of the chromophore. Further, the described plane forms the dihedral angle of $83.10(5)^{\circ}$ with the benzene ring of the BzMedtc anion and dihedral angles of $67.90(5)^{\circ}, 69.63(5)^{\circ}$ and $47.85(4)^{\circ}$ with the benzene rings of $\mathrm{PPh}_{3}$ containing the $\mathrm{C} 30, \mathrm{C} 40$, and C50 atoms, respectively. Mutual orientation of the phenyl groups of $\mathrm{PPh}_{3}$ within the molecular structure of 4 can be described by the 67.64(6) ${ }^{\circ}$ (between benzene rings containing $\mathrm{C} 30$ and $\mathrm{C} 40$ ), $66.06(6)^{\circ}$ (between benzene rings containing $\mathrm{C} 30$ and $\mathrm{C} 50$ ) and $76.53(6)^{\circ}$ (between benzene rings containing C40 and C50) dihedral angles. The $\mathrm{C}-\mathrm{H} \cdots \mathrm{C}, \mathrm{C}-\mathrm{H} \cdots \mathrm{S}$ and $\mathrm{C} \cdots \mathrm{C}$ types of the intermolecular non-bonding van der Waals contacts were detected to stabilize the crystal structure of $\mathbf{4}$ (see Table 4). No typical hydrogen bond is present within the structure of discussed complex.

Table 3: Selected bond lengths $(\AA)$ and angles $\left({ }^{\circ}\right)$ for the complexes [Ni(NCS)(BzMedtc) $\left.\left(\mathrm{PPh}_{3}\right)\right]$ (4) and [Ni(BzMedtc) $\left.\left(\mathrm{PPh}_{3}\right)_{2}\right] \mathrm{ClO}_{4} \cdot \mathrm{H}_{2} \mathrm{O}\left(\mathbf{5} \cdot \mathrm{H}_{2} \mathrm{O}\right)$

\begin{tabular}{|c|c|c|}
\hline Compound & 4 & $5 \cdot \mathrm{H}_{2} \mathrm{O}$ \\
\hline \multicolumn{3}{|l|}{ Bond Lengths } \\
\hline Ni1-S1 & $2.2245(5)$ & $2.2154(6)$ \\
\hline Ni1-S2 & $2.1758(5)$ & $2.2257(6)$ \\
\hline Ni1-P1 & $2.2162(5)$ & $2.2165(6)$ \\
\hline $\mathrm{Ni1}-\mathrm{P} 2$ & - & $2.2316(6)$ \\
\hline $\mathrm{Ni1}-\mathrm{N} 2$ & $1.8564(17)$ & - \\
\hline $\mathrm{C} 1-\mathrm{S} 1$ & $1.7125(19)$ & $1.731(2)$ \\
\hline $\mathrm{C} 1-\mathrm{S} 2$ & $1.7214(19)$ & $1.721(2)$ \\
\hline $\mathrm{C} 1-\mathrm{N} 1$ & $1.306(2)$ & $1.307(3)$ \\
\hline $\mathrm{N} 2-\mathrm{C} 4$ & $1.163(2)$ & - \\
\hline $\mathrm{C} 4-\mathrm{S} 3$ & $1.621(2)$ & - \\
\hline \multicolumn{3}{|l|}{ Bond Angles } \\
\hline S1-Ni1-S2 & 78.643(19) & $78.29(2)$ \\
\hline S1-Ni1-P1 & $171.63(2)$ & $91.28(2)$ \\
\hline $\mathrm{S} 1-\mathrm{Ni} 1-\mathrm{N} 2$ & $92.06(5)$ & - \\
\hline S1-Ni1-P2 & - & $167.08(2)$ \\
\hline S2-Ni1-P1 & $93.384(19)$ & $167.76(2)$ \\
\hline S2-Ni1-P2 & - & $88.91(2)$ \\
\hline S2-Ni1-N2 & $170.70(5)$ & - \\
\hline P1-Ni1-N2 & $95.91(5)$ & - \\
\hline $\mathrm{P} 1-\mathrm{Ni1}-\mathrm{P} 2$ & - & $101.24(2)$ \\
\hline Ni1-S1-C1 & $85.71(7)$ & $86.52(8)$ \\
\hline Ni1-S2-C1 & $87.04(7)$ & $86.42(8)$ \\
\hline $\mathrm{S} 1-\mathrm{C} 1-\mathrm{S} 2$ & $108.60(11)$ & 108.61(12) \\
\hline $\mathrm{S} 1-\mathrm{C} 1-\mathrm{N} 1$ & $125.67(15)$ & $126.50(17)$ \\
\hline $\mathrm{S} 2-\mathrm{C} 1-\mathrm{N} 1$ & $125.73(15)$ & $124.89(17)$ \\
\hline $\mathrm{Ni1}-\mathrm{N} 2-\mathrm{C} 4$ & $167.29(16)$ & - \\
\hline $\mathrm{N} 2-\mathrm{C} 4-\mathrm{S} 3$ & $178.52(19)$ & - \\
\hline
\end{tabular}

In the case of $\mathbf{5} \cdot \mathrm{H}_{2} \mathrm{O}$, the $\mathrm{Ni}(\mathrm{II})$ ion is four-coordinated in the distorted square-planar geometry (Figure 2), similarly to the above described structure of complex 4 , by the bidentate-coordinated S-donor BzMedtc ligand and by two $\mathrm{P}$-donor $\mathrm{PPh}_{3}$ molecules. Selected bond lengths and angles are given in Table 3. The positive charge of the $\left[\mathrm{Ni}(\mathrm{BzMedtc})\left(\mathrm{PPh}_{3}\right)_{2}\right]^{+}$cation is compensated by the perchlorate anion; the shortest $\mathrm{Ni1} \cdots \mathrm{Cl} 1$ distance equals 7.131(2) ^.

Table 4 Selected intermolecular non-bonding contacts and their parameters $\left(\AA,^{\circ}\right)$ determined for the complexes $\mathbf{4}$ and $\mathbf{5} \cdot \mathrm{H}_{2} \mathrm{O}$

\begin{tabular}{lcccc}
\hline $\mathrm{D}-\mathrm{H} \cdots \mathrm{A}$ & $d(\mathrm{D}-\mathrm{H})$ & $d(\mathrm{H} \cdots \mathrm{A})$ & $d(\mathrm{D} \cdots \mathrm{A})$ & $<(\mathrm{DHA})$ \\
\hline $\mathbf{4}$ & & & & \\
$\mathrm{C} 3-\mathrm{H} 3 \mathrm{~A} \cdots \mathrm{S} 3^{\mathrm{i}}$ & 0.990 & $2.9234(6)$ & $3.666(2)$ & $132.43(12)$ \\
$\mathrm{C} 34-\mathrm{H} 34 \mathrm{~A} \cdots \mathrm{S} 2^{\mathrm{ii}}$ & 0.950 & $2.9389(5)$ & $3.717(2)$ & $139.90(12)$ \\
$\mathrm{C} 32-\mathrm{H} 32 \mathrm{~A} \cdots \mathrm{S} 3^{\mathrm{iii}}$ & 0.950 & $2.8695(6)$ & $3.814(2)$ & $172.48(12)$ \\
$\mathrm{C} 31-\mathrm{H} 31 \mathrm{~A} \cdots \mathrm{S} 1^{\mathrm{iii}}$ & 0.950 & $2.9701(6)$ & $3.883(2)$ & $161.56(12)$ \\
$\mathrm{C} 2 \cdots \mathrm{C} 32$ & & & $3.307(3)$ & \\
$\mathbf{5} \cdot \mathrm{H}_{2} \mathrm{O}$ & & & & \\
$\mathrm{C} 74-\mathrm{H} 74 \mathrm{~A} \cdots \mathrm{C} 32^{\mathrm{iv}}$ & 0.950 & $2.771(3)$ & $3.678(4)$ & $160.13(16)$ \\
$\mathrm{C} 72-\mathrm{H} 72 \mathrm{~A} \cdots \mathrm{C} 54^{\mathrm{v}}$ & 0.950 & $2.781(2)$ & $3.554(3)$ & $139.11(16)$ \\
$\mathrm{C} 2-\mathrm{H} 2 \mathrm{~B} \cdots \mathrm{C} 74^{\text {iv }}$ & 0.990 & $2.844(2)$ & $3.771(3)$ & $156.25(14)$ \\
$\mathrm{C} 14-\mathrm{H} 14 \mathrm{~A} \cdots \mathrm{C} 33^{\mathrm{vi}}$ & 0.950 & $2.746(3)$ & $3.666(4)$ & $163.31(16)$ \\
$\mathrm{C} 13-\mathrm{H} 13 \mathrm{~A} \cdots \mathrm{C} 3^{\mathrm{v}}$ & 0.950 & $2.879(2)$ & $3.815(3)$ & $168.16(14)$ \\
$\mathrm{C} 44-\mathrm{H} 44 \mathrm{~A} \cdots \mathrm{C} 64^{\mathrm{vii}}$ & 0.950 & $2.872(3)$ & $3.653(4)$ & $140.17(16)$ \\
$\mathrm{C} 13 \cdots \mathrm{C} 71^{\mathrm{v}}$ & & & $3.262(4)$ & \\
$\mathrm{C} 70 \cdots \mathrm{C} 70^{\mathrm{iv}}$ & & & $3.391(3)$ & \\
\hline
\end{tabular}

Symmetry codes: (i) $\mathrm{x}+0.5,0.5-\mathrm{y}, \mathrm{z}-0.5$; (ii) $1-\mathrm{x}, 1-\mathrm{y}, 1-\mathrm{z}$; (iii) $1.5-\mathrm{x}, \mathrm{y}+0.5,1.5-\mathrm{z}$; (iv) $-\mathrm{x},-\mathrm{y},-\mathrm{z}$; (v) $-\mathrm{x}, 1-\mathrm{y},-\mathrm{z}$; (vi) 1 $-\mathrm{x}, 1-\mathrm{y},-\mathrm{z}$; (vii) $-\mathrm{x}, 1-\mathrm{y}, 1-\mathrm{z}$

As it has been already mentioned in the case of complex $\mathbf{4}$, the bond lengths within the $\mathrm{NiS}_{2} \mathrm{CN}$ moiety of both structures show on electron density redistribution in connection with $\pi$-electron density delocalization (see the $\mathrm{C}-\mathrm{S}$ and $\mathrm{C}-\mathrm{N}$ bond lengths in Table 3 ). As for the $\mathrm{Ni}-\mathrm{P}$ bonds of $\mathbf{5}$, their lengths are in good agreement with the mean value of $2.208 \AA(2.175-2.252 \AA$ interval $)$ as determined from $36 \mathrm{X}$-ray structures of tetra-coordinated nickel dithiocarbamato complexes involving at least one $\mathrm{PPh}_{3}$ ligand and deposited within the CSD.

The S2 atom is the most deviated one [0.0903(6) $\AA$ ] from the plane created through the atoms of the chromophore. The dihedral angles between this plane and benzene rings involving $\mathrm{C} 10, \mathrm{C} 20, \mathrm{C} 30, \mathrm{C} 40, \mathrm{C} 50, \mathrm{C} 60$, and $\mathrm{C} 70$ are $86.39(5)^{\circ}, \quad 58.49(7)^{\circ}, \quad 87.97(5)^{\circ}, \quad 70.52(5)^{\circ}, \quad 71.64(5)^{\circ}$, $63.60(6)^{\circ}$, and $71.98(5)^{\circ}$, respectively. Non-bonding interactions of the $\mathrm{C}-\mathrm{H} \cdots \mathrm{C}$ and $\mathrm{C} \cdots \mathrm{C}$ types $(\mathrm{C}-\mathrm{H} \cdots \mathrm{O}$ interactions with the distorted perchlorate anion and water molecule of crystallization are disregarded) were found in the crystal structure of the discussed nickel(II) complex (Table 4).

\section{TG/DTA Thermal Analysis}

The thermal properties of the prepared nickel(II) complexes were studied by TG and DTA methods. The TG and DTA curves of $\mathbf{1}$ and $\mathbf{6}$ are depicted in Figure 3. Although the chemical composition of these complexes is different, their thermal decomposition proceeded in a similar manner as indicated by analogical shapes of the TG curves. In cases of 2,3 and $\mathbf{6}$, the sharp exo-effects with maxima at $188^{\circ} \mathrm{C}, \quad 193^{\circ} \mathrm{C}$, and $188^{\circ} \mathrm{C}$, respectively, were accompanied by mass increase on the TG curves, which can be attributed to the oxygen atom insertion into the $\mathrm{Ni}-\mathrm{P}$ bond [29]. This effect was not registered on the TG curves of the remaining complexes, where the oxygen atom 


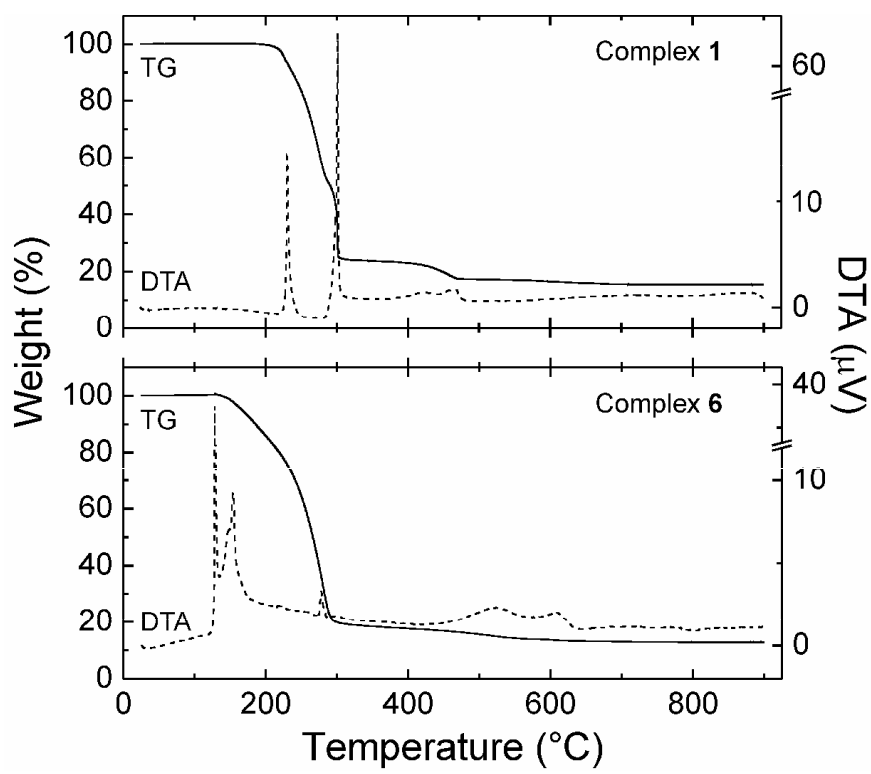

Figure 3. TG/DTA curves for complexes 1 and $\mathbf{6}$.

insertion is most likely combined with the decomposition of the organic parts of the studied complexes.

The final products of the TG studies $\left(900{ }^{\circ} \mathrm{C}\right)$ were studied by X-ray powder diffraction (XRD). NiO (PDF-4 No. 01-089-7130) was determined as the final product of the thermal decomposition of 1-4. In the cases of the complexes 6 and 7, the mixtures with significant predominance of $\mathrm{NiO}$ were detected. The final product of the TG thermal study of 6 also contains NiS (PDF-4 No. 4-004-5027) and $\mathrm{Ni}_{3} \mathrm{~B}_{2} \mathrm{O}_{6}$ (PDF-4 No. 4-008-3203), and some peaks could not be assigned. As for the complex 7, $\mathrm{Ni}_{2} \mathrm{P}_{2} \mathrm{O}_{7}$ (PDF-4 No. 01-074-1604) and $\mathrm{Ni}_{3}\left(\mathrm{PO}_{4}\right)_{2}$ (PDF-4 No. 01-072-3977) were detected by a XRD, while some peaks were not assigned.

\section{Catalytic Influence of the Complexes on Graphite Oxidation}

The influence of the presence of the representative complexes $\mathbf{1}, \mathbf{3}, \mathbf{5}$ and $\mathbf{6}$ on graphite oxidation were studied. The results, summarized in Figure 4 (obtained DTG curves) and Table 5 (obtained data), showed an positive influence on graphite oxidation, because the ignition temperature significantly decreased (by about $64-99^{\circ} \mathrm{C}$ ) after the addition of the tested nickel(II) complexes to a pure graphite.

Pure graphite oxidation proceeds in one step, while in the cases of its mixtures with the tested complexes, two steps in a larger temperature interval were detected on the appropriate DTG curves (Table 5). The first step takes place at lower temperature than pure graphite oxidation, whereas the oxidation rate maxima $\left(T_{m}\right)$ of the second step approximately correspond to pure graphite. In addition, the oxidation mechanisms of both steps are different, as it can be seen from the activation energy $(E)$ and frequency factor $(A)$ values given in Table 5. More graphite was oxidized during the second step with higher $E$ and $A$ values.
At this point, we would like to discuss the described results of the influence on the graphite oxidation in connection with the results of TG/DTA studies. Figure 3 clearly shows that the thermal decomposition of the nickel(II) complexes is almost completely finished at the temperature of ca. $700{ }^{\circ} \mathrm{C}$ and the weight loss above this temperature is insignificant. Based on this statement it may be concluded that not directly the discussed nickel(II) $\mathrm{N}$ benzyl- $N$-methyldithiocarbamato complexes, but the products of their thermal decomposition processes, affected graphite oxidation.

Table 5: Characteristic temperatures and kinetic parameters of catalytic influence on graphite given for pure graphite and its mixtures with nickel(II) complexes $\mathbf{1}, \mathbf{3}, \mathbf{5}$ and $\mathbf{6}$

\begin{tabular}{llllllll}
\hline Sample & $T\left({ }^{\circ} \mathrm{C}\right)$ & $T_{m}\left({ }^{\circ} \mathrm{C}\right)$ & Step & $n$ & $A\left(\mathrm{~s}^{-1}\right)$ & $E$ & $w(\%)$ \\
\hline Graphite & $778-859$ & 832 & & 0.7 & $1.97 \times 10^{9}$ & 247 & \\
$\mathbf{1}$ & $679-838$ & 792 & I & 1.3 & $3.62 \times 10^{7}$ & 190 & 43.58 \\
& & & II & 0.9 & $1.09 \times 10^{9}$ & 235 & 56.42 \\
$\mathbf{3}$ & $696-879$ & 838 & I & 0.9 & $4.08 \times 10^{6}$ & 174 & 34.48 \\
& & & II & 0.9 & $9.10 \times 10^{7}$ & 220 & 65.52 \\
$\mathbf{5}$ & $693-860$ & 815 & I & 1.0 & $1.47 \times 10^{7}$ & 183 & 36.06 \\
& & & II & 1.0 & $4.08 \times 10^{9}$ & 250 & 63.94 \\
$\mathbf{6}$ & $714-861$ & 812 & I & 0.8 & $5.88 \times 10^{6}$ & 176 & 23.48 \\
& & & II & 1.1 & $1.17 \times 10^{9}$ & 238 & 76.52 \\
\hline
\end{tabular}

$T=$ temperature range of oxidation; $T_{m}=$ oxidation rate maximum $n=$ reaction order; $A=$ frequency factor; $E=$ activation energy $(\mathrm{kJ}$ $\left.\mathrm{mol}^{-1}\right) ; w=$ mass of sample oxidized

In connection with the above-mentioned facts, the tested complexes (except of 5) were heated in situ to the temperatures corresponding to the beginning and end of graphite oxidation (see Table 5). The products of thermal decomposition relating to the mentioned temperatures were analysed by XRD. As for 1-4, pure $\mathrm{NiO}$ was identified at both temperatures (Figure 5). The slight differences in the $2 \theta$ values were caused by a dilatation of the sample due to different measurement temperature. On the other hand, the mixtures of $\mathrm{NiO}$, NiS and $\mathrm{Ni}_{3} \mathrm{~B}_{2} \mathrm{O}_{6}$ (for 6) and $\mathrm{Ni}_{2} \mathrm{P}_{2} \mathrm{O}_{7}$ and

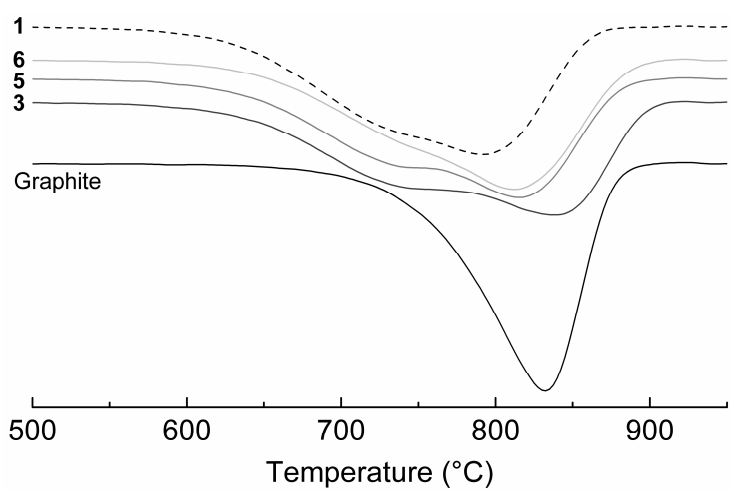

Figure 4. DTG curves obtained for pure graphite (black lines) and its mixture with the complexes $\mathbf{1}$ (black dashed lines), $\mathbf{3}$ (dark gray line), $\mathbf{5}$ (gray line) and $\mathbf{6}$ (light gray line); the tangent method was employed to determine the initial temperatures of the graphite oxidation 


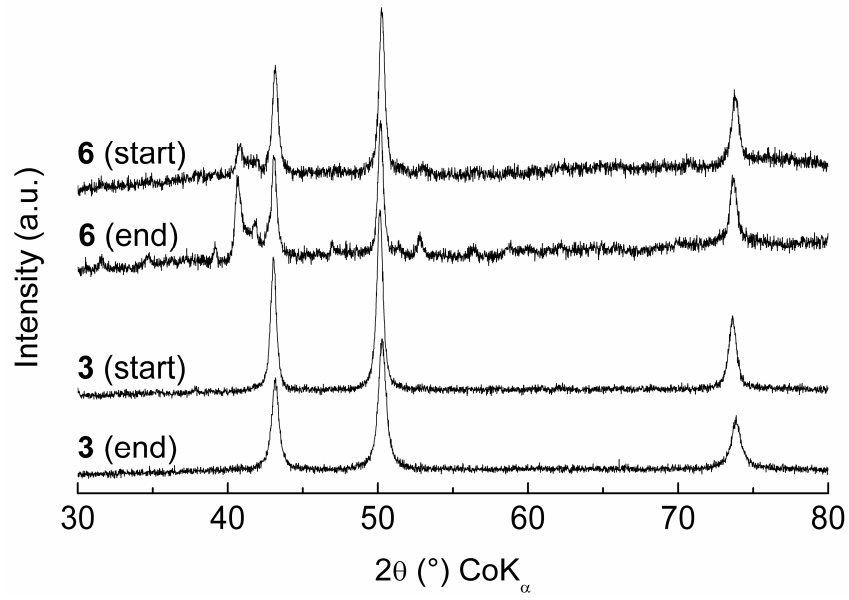

Figure 5. XRD patterns of the thermal decomposition products of the complexes $\mathbf{3}$ and $\mathbf{6}$. The detected diffraction lines belong to $\mathrm{NiO}$ for 3, and $\mathrm{NiO}, \mathrm{NiS}$ and $\mathrm{Ni}_{3} \mathrm{~B}_{2} \mathrm{O}_{6}$ for 6; the start and end temperatures are given in Table 5.

$\mathrm{Ni}_{3}\left(\mathrm{PO}_{4}\right)_{2}$ (for 7) were detected by an XRD (Figure 5). Their quantitative composition was similar at both temperatures. Some peaks could not be assigned again.

\section{Conclusions}

Seven nickel(II) complexes of the $\left[\mathrm{Ni}(\mathrm{BzMedtc})\left(\mathrm{PPh}_{3}\right) \mathrm{X}\right]$ (1-4) and [Ni(BzMedtc) $\left.\left(\mathrm{PPh}_{3}\right)_{2}\right] \mathrm{Y}$ (5-7) compositions were synthesized; $\mathrm{X}=\mathrm{Cl}^{-}$for $\mathbf{1}, \mathrm{Br}^{-}$for $\mathbf{2}, \mathrm{I}^{-}$for $\mathbf{3}$ and $\mathrm{NCS}^{-}$for $\mathbf{4}$, $\mathrm{Y}=\mathrm{ClO}_{4}^{-}$for $5, \mathrm{BPh}_{4}^{-}$for $\mathbf{6}$ and $\mathrm{PF}_{6}^{-}$for 7 ). The obtained powder products were fully characterized by elemental analysis, magnetochemical and molar conductivity measurements, thermal analysis and spectroscopic methods (IR, UV-Vis, ${ }^{31} \mathrm{P}\left\{{ }^{1} \mathrm{H}\right\}$-NMR). The molecular structures of the complexes [Ni(BzMedtc) $\left.\left(\mathrm{PPh}_{3}\right)(\mathrm{NCS})\right]$ (4) and $\left[\mathrm{Ni}(\mathrm{BzMedtc})\left(\mathrm{PPh}_{3}\right)_{2}\right] \mathrm{ClO}_{4} \cdot \mathrm{H}_{2} \mathrm{O} \quad\left(\mathbf{5} \cdot \mathrm{H}_{2} \mathrm{O}\right)$ were determined by a single crystal $\mathrm{X}$-ray analysis, which proved the distorted square-planar geometry with the bidentatecoordinated S-donor BzMedtc anion accompanied by $\mathrm{PPh}_{3}$ and $\mathrm{NCS}^{-}(\mathbf{4})$ or by two $\mathrm{PPh}_{3}(\mathbf{5})$. This paper also describes the significant catalytic influence of the thermal degradation products of the selected complexes $\mathbf{1 , 3 , 5}$, and $\mathbf{6}$ on graphite oxidation.

\section{Experimental Section}

\section{Materials and General Methods}

Chemicals and solvents were purchased from Sigma-Aldrich Co., Acros Organics Co., Lachema Co. and Fluka Co. and they were used as received. The starting compounds [Ni(BzMedtc) $)_{2}$, $\left[\mathrm{Ni}\left(\mathrm{PPh}_{3}\right) 2 \mathrm{Cl}_{2}\right], \quad\left[\mathrm{Ni}_{(}\left(\mathrm{PPh}_{3}\right)_{2} \mathrm{Br}_{2}\right], \quad\left[\mathrm{Ni}_{(}\left(\mathrm{PPh}_{3}\right)_{2} \mathrm{I}_{2}\right] \quad$ and $\left[\mathrm{Ni}\left(\mathrm{PPh}_{3}\right)_{2}(\mathrm{NCS})_{2}\right]$ were prepared according to the formerly reported synthetic pathways [13,30].

Elemental analyses $(\mathrm{C}, \mathrm{H}, \mathrm{N})$ were performed on a Fisons EA-1108 CHNS-O Elemental Analyzer (Thermo Scientific). The content of nickel was determined using the chelatometric titration with murexide as an indicator. Chlorine, bromine and iodine contents were determined by the Schöniger method. Diffuse-reflectance spectra were recorded on a Perkin-Elmer Lamda35 UV/Vis spectrometer using a nujol technique. IR spectra ( $\mathrm{KBr}$ pellets) were recorded on a Perkin-Elmer Spectrum one FT-IR spectrometer in the $450-4000 \mathrm{~cm}^{-1}$ region. The molar conductivity values of $10^{-3}$ $\mathrm{M}$ acetone solutions of $\mathbf{1 - 5}$ and $5 \times 10^{-4} \mathrm{M}$ $N, N^{\prime}$-dimethylformamide (DMF) solutions of $\mathbf{6}$ and $\mathbf{7}$ were determined by an LF 330/SET conductometer (WTW GmbH) at 25 ${ }^{\circ} \mathrm{C}$. The room temperature magnetic susceptibilities were measured using the Faraday method with a laboratory designed instrument with a Sartorius 4434 MP-8 microbalance; $\mathrm{Co}\left[\mathrm{Hg}(\mathrm{NCS})_{4}\right]$ was used as a calibrant and the correction for diamagnetism was performed using Pascal constants. Simultaneous thermogravimetric (TG) and differential thermal (DTA) analyses were performed by an Exstar TG/DTA 6200 (Seiko Instruments Inc.) in a platinum crucible and dynamic air atmosphere $\left(100 \mathrm{~mL} \mathrm{~min}^{-1}\right)$ from the laboratory temperature to $1050{ }^{\circ} \mathrm{C}$ with a $2.5{ }^{\circ} \mathrm{C} \mathrm{min}-1$ temperature gradient. The weights of the studied complexes 1-4, $\mathbf{6}$ and $\mathbf{7}$ (5 was not studied for safety reasons, since it contains the perchlorate anion) were ca. $10 \mathrm{mg} .{ }^{31} \mathrm{P}\left\{{ }^{1} \mathrm{H}\right\}$-NMR spectra of the $\mathrm{CDCl}_{3}$ solutions were measured on a Bruker Avance 300 spectrometer at $300 \mathrm{~K}$ and the spectra were calibrated against $85 \% \mathrm{H}_{3} \mathrm{PO}_{4}$ used as an external reference. $\mathrm{X}$-ray powder diffraction experiments were performed with a PANalytical X'Pert PRO instrument (Co-K $\alpha$ radiation) equipped with an $\mathrm{X}^{\prime}$ Celerator detector. Samples were placed on a zero-background Si slide and scanned in the $2 \theta$ range of $5-90^{\circ}$ in the steps of $0.017^{\circ}$. In situ measurements were realized in the reaction cell XRK900 (Anton Paar). Evaluation was made using HighScore Plus software and PDF-4 database.

\section{Single Crystal $X$-ray Analysis of the Complexes 4 and $5 \cdot \mathrm{H}_{2} \mathrm{O}$}

A single crystal X-ray measurement was performed on an Xcalibur $^{\mathrm{TM}} 2$ diffractometer (Oxford Diffraction Ltd.) with Sapphire2 CCD detector, and with Mo Ka (Monochromator Enhance, Oxford Diffraction Ltd.) and at $113 \mathrm{~K}(\mathbf{4})$ and $110 \mathrm{~K}$ $\left(5 \cdot \mathrm{H}_{2} \mathrm{O}\right)$. Data collection and reduction were performed by a CrysAlis software [CrysAlis CCD and CrysAlis RED, Version 1.171.33.52, Oxford Diffraction Ltd., Abingdon, England, 2009]. The same software was used for data correction for an absorption effect by the empirical absorption correction using spherical harmonics, implemented in SCALE3 ABSPACK scaling algorithm. Both structures were solved by direct methods using SHELXS-97 software [31] and refined on $F^{2}$ using the full-matrix least-squares procedure (SHELXL-97). Non-hydrogen atoms were refined anisotropically and all hydrogen atoms were located in difference Fourier maps and refined by using the riding model with $\mathrm{C}-\mathrm{H}=$ $0.95,0.98$ and $0.99 \AA$, and $U_{\text {iso }}(\mathrm{H})=1.2 U_{\mathrm{eq}}\left(\mathrm{CH}, \mathrm{CH}_{2}\right)$ or $1.5 U_{\mathrm{eq}}\left(\mathrm{CH}_{3}\right)$, except for those belonging to the crystal water molecule in 5. The perchlorate anion as well as crystal water molecule was refined as disordered over two positions with the occupancy factors $75 \%$ and $25 \%$, and $57 \%$ and $43 \%$, respectively. The crystal data and structure refinements of $\mathbf{4}$ and $\mathbf{5}$ are given in Table 1. The molecular graphics were drawn and the additional structural calculations were interpreted using DIAMOND [32]. Crystallographic data have been deposited with the Cambridge Crystallographic Data Centre, 12 Union Road, Cambridge CB21EZ, UK (Fax: +44-1223-336033; E-Mail: deposit@ccdc.cam.ac.uk). Copies of the data can be obtained free of charge on application to CCDC, as the depository numbers CCDC-766048 (4) and CCDC$766049\left(5 \cdot \mathrm{H}_{2} \mathrm{O}\right)$. 


\section{The Catalytic Study}

Graphite $(0.6 \mathrm{~g}$, diameter of particles less than $0.1 \mathrm{~mm}$, ash residue max. $0.2 \%$, mass drying loss max. $0.2 \%$ ) was mixed with an acetone solution ( $2 \mathrm{~mL}$ ) of the nickel(II) complex $\mathbf{1}, \mathbf{3}, \mathbf{5}$ or $\mathbf{6}(\mathbf{2}, \mathbf{4}$, and 7 were not studied because of their insufficient solubility in acetone) to give the final nickel concentration of $2.5 \mathrm{mmol} \mathrm{L}^{-1}$. The mixtures were homogenized and dried at room temperature for 24 $h$. The study of the catalytic influence of these samples on graphite was performed on a Netzsch STA $449 \mathrm{C}$ device with an $\alpha-\mathrm{Al}_{2} \mathrm{O}_{3}$ crucible without a standard $\left(10^{\circ} \mathrm{C} \mathrm{min}^{-1}\right.$ heating rate, sample weight of $5.0 \mathrm{mg}, 100 \mathrm{~mL} \mathrm{~min}^{-1}$ dynamic air atmosphere). The intersection point of the DTG curve tangents represents the initial temperatures of the graphite oxidation. The kinetic parameters were calculated by a direct non-linear regression method [33].

\section{Syntheses of the Nickel(II) Complexes 1-7}

[Ni(BzMedtc) $\left.\left(\mathbf{P P h}_{3}\right) \mathrm{Cl}\right] \quad(1), \quad\left[\mathrm{Ni}(\mathrm{BzMedtc})\left(\mathrm{PPh}_{3}\right) \mathrm{Br}\right] \quad$ (2), [Ni(BzMedtc) $\left.\left(\mathbf{P P h}_{3}\right)\right]$ (3) and [Ni(BzMedtc) $\left.\left(\mathbf{P P h}_{3}\right)(\mathbf{N C S})\right]$ (4): The complex $\mathbf{1}$ was synthesized using the reaction of [Ni(BzMedtc $\left.)_{2}\right](1 \mathrm{mmol})$ and $\left[\mathrm{NiCl}_{2}\left(\mathrm{PPh}_{3}\right)_{2}\right](1 \mathrm{mmol})$. Both starting compounds were suspended in $25 \mathrm{~mL}$ of chloroform $\left(\mathrm{CHCl}_{3}\right)$. The mixture was stirred at room temperature until the reaction components were completely dissolved. The resulting solution was filtered through activated carbon. Diethyl ether was added to the filtrate which was left to stand at laboratory temperature. The precipitate of $\mathbf{1}$ formed in a few days. The product was filtered off, washed with diethyl ether and dried at $40{ }^{\circ} \mathrm{C}$ under an infrared lamp. The complexes 2-4 were prepared as described for $\mathbf{1}$, but $\left[\mathrm{NiBr}_{2}\left(\mathrm{PPh}_{3}\right)_{2}\right]$ (for 2), $\left[\mathrm{NiI}_{2}\left(\mathrm{PPh}_{3}\right)_{2}\right]$ (for 3) and $\left[\mathrm{Ni}(\mathrm{NCS})_{2}\left(\mathrm{PPh}_{3}\right)_{2}\right]$ (for 4 ) were used instead of $\left[\mathrm{NiCl}_{2}\left(\mathrm{PPh}_{3}\right)_{2}\right]$. In the case of the complex $\mathbf{4}$, the crystals suitable for a single crystal X-ray analysis were obtained from the mother liquor in two days. [Ni(BzMedtc) $\left(\mathbf{P P h}_{\mathbf{3}}\right) \mathbf{C l}$ ] (1): Yield: $78 \%$. Colour: violet. $\mathrm{C}_{27} \mathrm{H}_{25} \mathrm{NS}_{2} \mathrm{PClNi}\left(\mathrm{M}_{\mathrm{r}}=552.8\right) ; \mathrm{C} 58.7$ (calc. 58.4); H 4.6 (4.6); $\mathrm{N}$ 2.5 (2.4); S 11.6 (11.3); Cl 6.4 (6.5); Ni 10.6 (10.6)\%. TG/DTA data: the decomposition began at $177{ }^{\circ} \mathrm{C}$ and finished at $704{ }^{\circ} \mathrm{C}$ with the experimental weight loss of $84.5 \%$ (calc. to $\mathrm{NiO}$ residue: $86.5 \%$ ), exothermic peaks with the maxima at $231,302,420$ and $463^{\circ} \mathrm{C}$

[Ni(BzMedtc) $\left(\mathbf{P P h}_{3}\right) \mathbf{B r}$ ] (2): Yield: 90\%. Colour: violet. $\mathrm{C}_{27} \mathrm{H}_{25} \mathrm{NS}_{2} \mathrm{PBrNi}\left(\mathrm{M}_{\mathrm{r}}=597.2\right)$; 54.3 (calc. 54.2); H 4.2 (4.1); N 2.3 (2.0); S 10.7 (10.3); $\mathrm{Br} 13.4$ (13.1); Ni 9.8 (9.6)\%. TG/DTA data: the decomposition began at $156{ }^{\circ} \mathrm{C}$ and finished at $1000{ }^{\circ} \mathrm{C}$ with the weight loss of $86.0 \%$ (calc. to $\mathrm{NiO}$ residue: $87.5 \%$ ), exothermic peaks with the maxima at $188,282,398$ and $490{ }^{\circ} \mathrm{C}$. [Ni(BzMedtc) $\left(\mathbf{P P h}_{3}\right)$ ] (3): Yield: 70\%. Colour: dark violet. $\mathrm{C}_{27} \mathrm{H}_{25} \mathrm{NS}_{2} \mathrm{PINi}\left(\mathrm{M}_{\mathrm{r}}=644.2\right)$; C 50.3 (calc. 49.9); H 3.9 (3.9); $\mathrm{N}$ 2.2 (2.2); S 10.0 (10.0); I 19.7 (19.3); Ni 9.1 (9.2)\%. TG/DTA data: the decomposition began at $180{ }^{\circ} \mathrm{C}$ and finished at $829^{\circ} \mathrm{C}$ with the weight loss of $86.6 \%$ (calc. to $\mathrm{NiO}$ residue: $88.4 \%$ ), endothermic peak with the maximum at $269{ }^{\circ} \mathrm{C}$ and exothermic peaks with the maxima at $193,246,301,457$ and $544{ }^{\circ} \mathrm{C}$.

[Ni(BzMedtc) $\left(\mathbf{P P h}_{\mathbf{3}}\right)(\mathbf{N C S})$ ] (4): Yield: 82\%. Colour: red. $\mathrm{C}_{28} \mathrm{H}_{25} \mathrm{~N}_{2} \mathrm{~S}_{3} \mathrm{PNi}\left(\mathrm{M}_{\mathrm{r}}=575.4\right) ; \mathrm{C} 58.5$ (calc. 58.9); $\mathrm{H} 4.4$ (4.1); $\mathrm{N}$ 4.9 (4.7); S 16.7 (16.6); Ni 10.2 (10.3)\%. TG/DTA data: the decomposition began at $155^{\circ} \mathrm{C}$ and finished at $1047{ }^{\circ} \mathrm{C}$ with the weight loss of $84.7 \%$ (calc. to $\mathrm{NiO}$ residue: $87.0 \%$ ), endothermic peak with the maximum at $198{ }^{\circ} \mathrm{C}$ and exothermic peaks with the maxima at $227,304,336,442$ and $541{ }^{\circ} \mathrm{C}$.
[Ni(BzMedtc) $\left.\left(\mathbf{P P h}_{3}\right)_{2}\right]_{\mathbf{C l O}}$ (5): $\mathrm{LiClO}_{4} \cdot 3 \mathrm{H}_{2} \mathrm{O} \quad(2 \mathrm{mmol})$ was poured to a suspension of the complex $1(1 \mathrm{mmol})$ and $\mathrm{PPh}_{3}(2$ mmol) in methanol $(25 \mathrm{~mL})$. The reaction mixtures were refluxed for $3 \mathrm{~h}$. The resulting solution was filtered through activated carbon and left to stand at room temperature. The crystals of $\mathbf{5} \cdot \mathrm{H}_{2} \mathrm{O}$ suitable for a single crystal X-ray analysis formed from the mother liquor in a few days. The complex was filtered off, washed with methanol and diethyl ether and dried at $40{ }^{\circ} \mathrm{C}$ under an infrared lamp. Yield: $47 \%$. Colour: pink. $\mathrm{C}_{45} \mathrm{H}_{40} \mathrm{NS}_{2} \mathrm{P}_{2} \mathrm{ClO}_{4} \mathrm{Ni}\left(\mathrm{M}_{\mathrm{r}}=879.0\right)$; C 61.5 (calc. 61.8); H 4.6 (4.3); N 1.6 (1.5); S 7.3 (6.9); Cl 4.2 (4.6); Ni 6.7 (6.8)\%.

[Ni(BzMedtc) $\left.\left(\mathbf{P P h}_{3}\right)_{2}\right] \mathbf{B P h}_{4}$ (6): $2 \mathrm{mmol}$ of $\mathrm{Na}\left[\mathrm{BPh}_{4}\right]$ was added to a suspension of $1(1 \mathrm{mmol})$ and $\mathrm{PPh}_{3}(2 \mathrm{mmol})$ in $25 \mathrm{~mL}$ of methanol. The pink solid appeared during $3 \mathrm{~h}$ of the reaction mixture refluxing. The product was removed by filtration, washed (methanol and diethyl ether) and dried at $40{ }^{\circ} \mathrm{C}$ under an infrared lamp. Yield: $69 \%$. Colour: pink. $\mathrm{C}_{69} \mathrm{H}_{60} \mathrm{NS}_{2} \mathrm{P}_{2} \mathrm{BNi}\left(\mathrm{M}_{\mathrm{r}}=1098.8\right)$; C 75.4 (calc. 75.1 ); H 5.5 (5.2); N 1.3 (1.5); S 5.8 (5.6); Ni 5.3 (5.7)\%. TG/DTA data: the decomposition began at $124{ }^{\circ} \mathrm{C}$ and finished at $764{ }^{\circ} \mathrm{C}$, exothermic peaks with the maxima at 128,154 , 178,524 and $607^{\circ} \mathrm{C}$.

[Ni(BzMedtc) $\left.\left(\mathbf{P P h}_{3}\right)_{2}\right] \mathbf{P F}_{6}$ (7): The solutions of $\mathrm{PPh}_{3}$ (2 mmol; 5 $\mathrm{mL}$ of acetone) and $\mathrm{K}\left[\mathrm{PF}_{6}\right](1 \mathrm{mmol} ; 7 \mathrm{~mL}$ of acetone) were separately added to a solution of $\mathbf{1}$ ( $1 \mathrm{mmol} ; 5 \mathrm{~mL}$ of chloroform). The reaction mixture was refluxed for a period of $4 \mathrm{~h}$ and after that it was filtered through activated carbon. Diethyl ether was added to the filtrate, which caused the formation of the precipitate. The solid was filtered off, washed with diethyl ether and dried at $40{ }^{\circ} \mathrm{C}$ under an infrared lamp. Yield: 54\%. Colour: red. $\mathrm{C}_{45} \mathrm{H}_{40} \mathrm{NS}_{2} \mathrm{P}_{3} \mathrm{~F}_{6} \mathrm{Ni}\left(\mathrm{M}_{\mathrm{r}}=\right.$ 924.5); C 58.5 (calc. 58.8); H 4.4 (4.6); N 1.6 (1.9); S 6.9 (6.5); Ni $6.3(6.7) \%$. TG/DTA data: the decomposition began at $99^{\circ} \mathrm{C}$ and finished at $782{ }^{\circ} \mathrm{C}$, exothermic peaks with the maxima at 188,207 , 310 and $472^{\circ} \mathrm{C}$.

\section{Acknowledgement}

This work was financially supported by The Ministry of Education, Youth and Sports of the Czech Republic (a grant no. MSM6198959218). The authors also thank Assoc. Prof. Zdeněk Šindelář for magnetic susceptibility measurements, and Dr. Jan Filip for X-Ray powder diffraction experiments.

\section{References}

[1] G. Hogarth, Prog. Inorg. Chem. 2005, 53, 71-561

[2] P. J. Nieuwenhuizen, A. W. Ehlers, J. G. Haasnoot, S. R. Janse, J. Reedijk, E. J. Baerends, J. Am. Chem. Soc. 1999, $121,163-168$

[3] S. L. Cao, Y. P. Feng, Y. Y. Jiang, S. Y. Liu, G. Y. Ding, R. T. Li, Bioorg. Med. Chem. 2005, 15, 1915-1917

[4] C. Gerhauser, M. You, J. Liu, R. M. Moriarty, M. Hawthorne, R. G. Metha, R. C. Moon, J. M. Pezzuto, Cancer Res. 1997, $57,272-278$

[5] S. Hidaka, T. Funakoshi, H. Shimada, M. Tsuruoka, S. Kojima, J. App. Toxicol. 1995, 15, 167-273

[6] C. Marzano, F. Bettio, F. Baccichetti, A. Trevisan, L. Giovagnini, D. Fregona, Chem. Biol. Interact. 2004, 148, 3748

[7] L. Ronconi, C. Marzano, P. Zanello, M. Corsini, G. Miolo, C. Macca, A. Trevisan, D. Fregona, J. Med. Chem. 2006, 49, 1648-1657 
[8] D. C. Menezes, F. T. Vieira, G. M. de Lima, A. O. Porto, M. E. Cortés, J. D. Ardisson, T. E. Albrecht Schmitt, Eur. J. Med. Chem. 2005, 40, 1277-1282

[9] F. A. Allen, Acta Crystallogr., Sect. B: Struct. Sci. 2002, 58, 380-388

[10] B. Arul Prakasam, K. Ramalingam, R. Baskaran, G. Bocelli, A. Cantoni, Polyhedron 2007, 26, 1133-1138

[11] M. R. L. Oliveira, J. Amim Jr., I. A. Soares, V. M. De Bellis, C. A. de Simone, C. Novais, S. Guilardi, Polyhedron 2008, 27, 727-733

[12] R. Pastorek, J. Kameníček, J. Husárek, V. Slovák, M. Pavlíček, J. Coord. Chem. 2007, 60, 485-494

[13] Z. Trávníček, R. Pastorek, V. Slovák, Polyhedron 2008, 27, 411-419

[14] X. Gong, Z. Guo, Z. Wang, Combust. Flame 2010, 157, 351356

[15] Z. H. Wu, L. Xu, Z. Z. Wang, Z. R. Zhang, Fuel 2008, 77, 891-893

[16] J. Carrazza, W. T. Tysoe, H. Heinemann, G. A. Somorjai, J. Catal. 1985, 96, 234-241

[17] W. J. Lee, S. D. Kim, Fuel 1995, 74, 1387-1393

[18] R. Pastorek, J. Kameníček, H. Vrbová, V. Slovák, M. Pavlíček, J. Coord. Chem. 2006, 59, 437-444

[19] R. Pastorek, J. Kameníček, B. Cvek, V. Slovák, M. Pavlíček, J. Coord. Chem. 2006, 59, 911-919

[20] W. J. Geary, Coord. Chem. Rev. 1971, 7, 81-122

[21] C. A. Tsipis, D. P. Kessissoglou, G. A. Katsoulos, Chim. Chron., New Series 1985, 14, 195

[22] S. V. Larionov, L. A. Patrina, I. M. Oglezneva, E. M. Uskov, Koord. Chim. 1984, 10, 92-99

[23] R. P. Scholer, E. A. Merbach, Inorg. Chim. Acta 1975, 15, $15-20$

[24] L. Ballester, A. Gutierrez, M. F. Perpinan, C. Ruiz-Valero, Polyhedron 1996, 15, 1103-1112

[25] A. B. P. Lever in Inorganic Electronic Spectroscopy (2nd edit), Elsevier, Amsterdam, 1984, p. 534

[26] C. A. Tsipis, D. P. Kessissoglou, G. E. Manoussakis, Inorg. Chim. Acta 1982, 65, L137-L141

[27] C. A. Tsipis, I. E. Meleziadis, D. P. Kessissoglou, G. A. Katsoulos, Inorg. Chim. Acta 1984, 90, L19-L22

[28] D. R. Lide (Ed.) in Handbook of Chemistry and Physics (73rd edit), CRC Press, Boca Raton, 1992

[29] F. Březina, E. Benátská, J. Thermal. Anal. 1981, 22, 75-79

[30] Gmelins Handbuch der Anorganischen Chemie, Nickel, Teil C, Lief. 2, Verlag Chemie, GmbH, Weinheim, 1969, p. 1043

[31] G. M. Sheldrick, Acta Cryst. 2008, A64, 112-122

[32] K. Brandenburg, DIAMOND, Release 3.1f, Crystal Impact GbR, Bonn, Germany, 2006

[33] V. Slovák, Thermochim. Acta 2001, 372, 175-182

Received: ((will be filled in by the editorial staff)) Published online: ((will be filled in by the editorial staff)) 


\section{Entry for the Table of Contents}

Seven nickel(II) $N$-benzyl- $N$-methyldithiocarbamato (BzMedtc) complexes were prepared and characterized. The structures of $\left[\mathrm{Ni}(\mathrm{BzMedtc})\left(\mathrm{PPh}_{3}\right)(\mathrm{NCS})\right](4)$ and $\left[\mathrm{Ni}(\mathrm{BzMedtc})\left(\mathrm{PPh}_{3}\right)_{2}\right] \mathrm{ClO}_{4} \cdot \mathrm{H}_{2} \mathrm{O}\left(\mathbf{5} \cdot \mathrm{H}_{2} \mathrm{O}\right)$ were determined by a single crystal X-ray analysis, which showed the $\mathrm{Ni}$ (II) centre as four-coordinated in a distorted square-planar geometry. The positive catalytic effect of the complexes $\mathbf{1}, \mathbf{3}, \mathbf{5}$, and $\mathbf{6}$ on the graphite oxidation was determined. The start temperatures of the oxidation of the complexes were by about $60-100{ }^{\circ} \mathrm{C}$ lower in comparison with pure graphite.

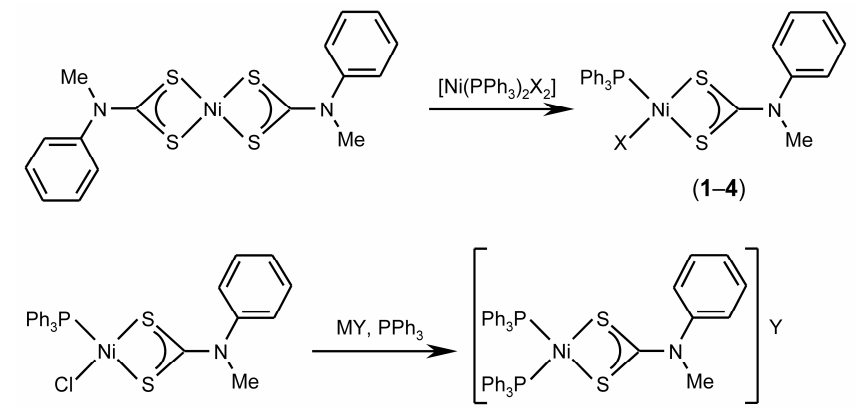

(1)
(5-7)

$\mathrm{X}=\mathrm{Cl}^{-}$(complex 1), $\mathrm{Br}^{-}(2), \mathrm{I}^{-}(3), \mathrm{NCS}^{-}(4)$ $\mathrm{Y}=\mathrm{ClO}_{4}^{-}(\mathbf{5}), \mathrm{BPh}_{4}^{-}(\mathbf{6}), \mathrm{PF}_{6}^{-}{ }^{-}(7)$

Zdeněk Trávníček, ${ }^{*[\mathrm{a}]}$ Richard Pastorek, ${ }^{[\mathrm{a}]}$ Pavel Štarha, ${ }^{[\mathrm{a}]}$ Igor Popa ${ }^{[a]}$ and Václav Slovák ${ }^{[b]}$

* Corresponding Author

Fax: +420585634357

E-Mail: zdenek.travnicek@upol.cz

Nickel(II) $N$-benzyl- $N$-methyldithiocarbamato complexes as precursors for the preparation of graphite oxidation accelerators 


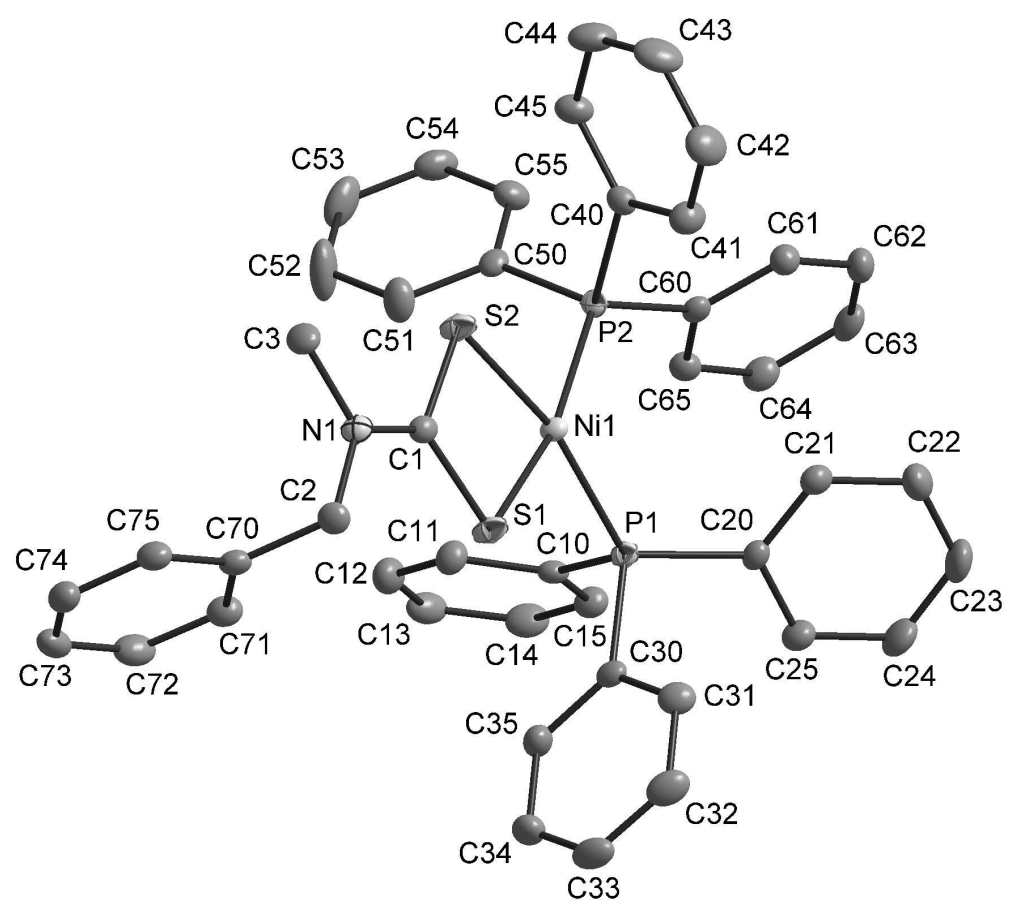

The molecular structure of $[\mathrm{Ni}(\mathrm{BzMedtc})(\mathrm{PPh} 3) 2] \mathrm{ClO} 4 \cdot \mathrm{H} 2 \mathrm{O}(5 \cdot \mathrm{H} 2 \mathrm{O})$ with non hydrogen atoms drawn as thermal ellipsoids at the $50 \%$ probability level. The hydrogen atoms, perchlorate anion and water molecule of crystallization were omitted for clarity. $1216 \times 926 \mathrm{~mm}(96 \times 96 \mathrm{DPI})$ 


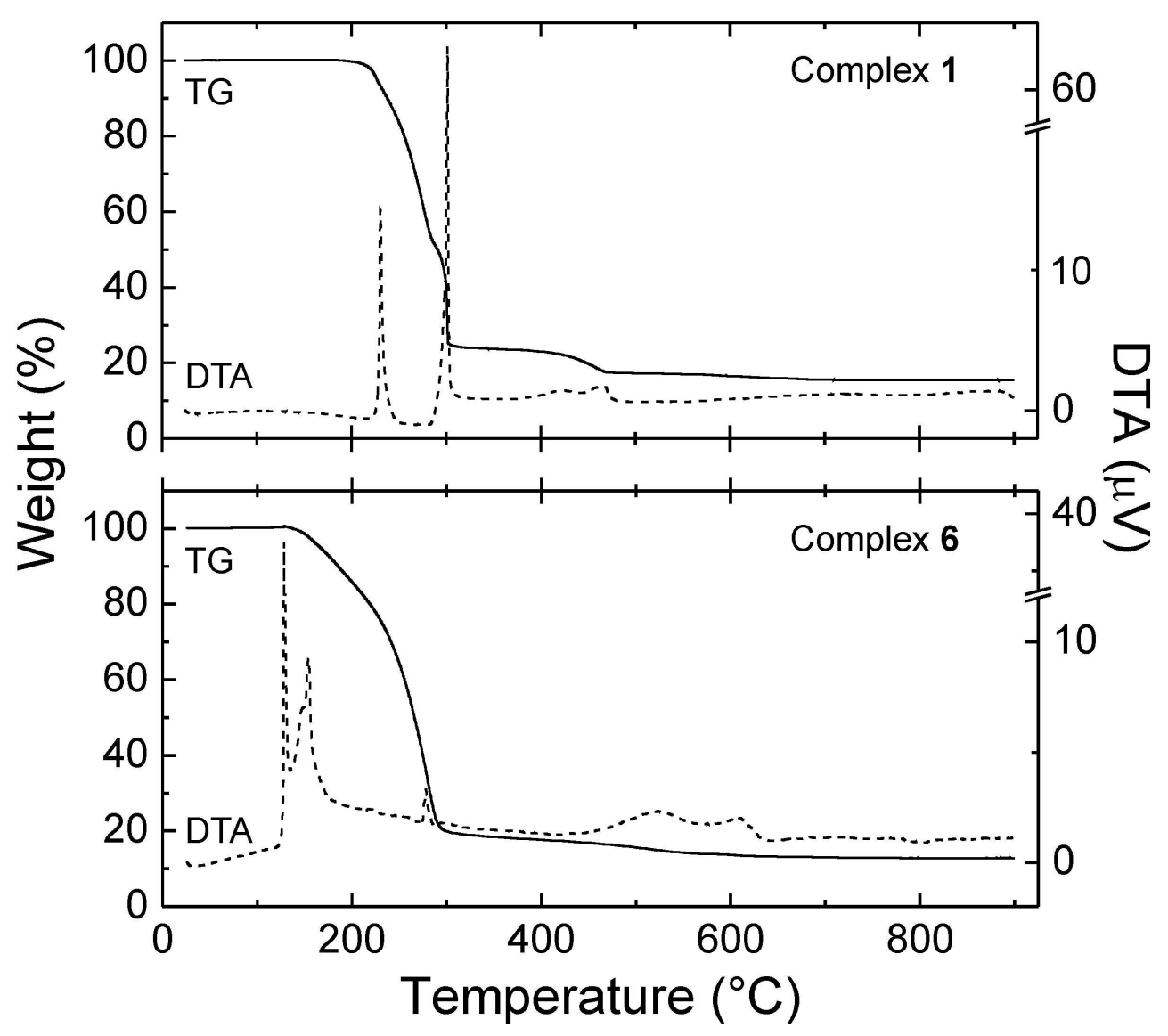

TG/DTA curves for complexes 1 and 6 . $103 \times 90 \mathrm{~mm}(600 \times 600$ DPI $)$ 


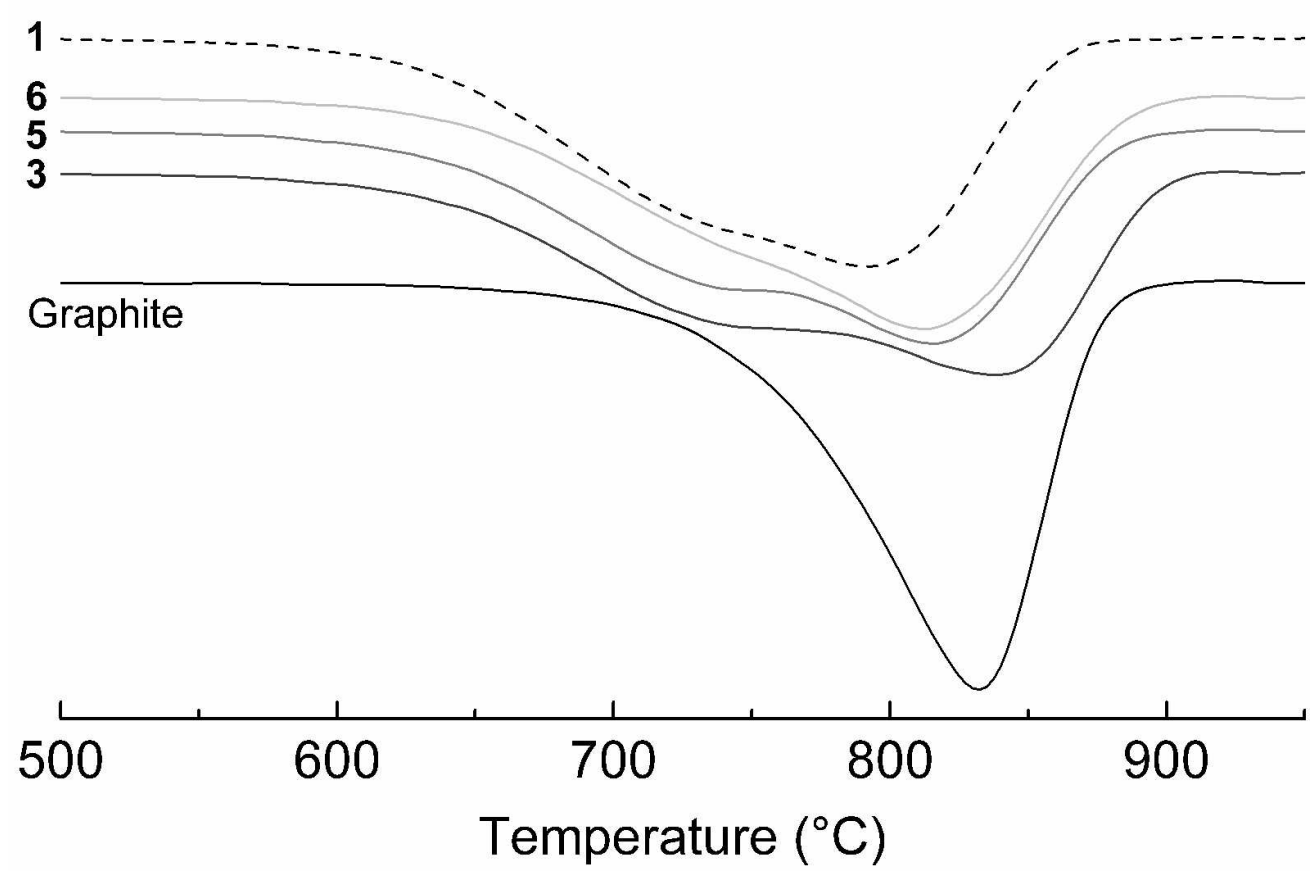

DTG curves obtained for pure graphite (black lines) and its mixture with the complexes 1 (black dashed lines), 3 (dark gray line), 5 (gray line) and 6 (light gray line); the tangent method was employed to determine the initial temperatures of the graphite oxidation $269 \times 192 \mathrm{~mm}(600 \times 600 \mathrm{DPI})$ 


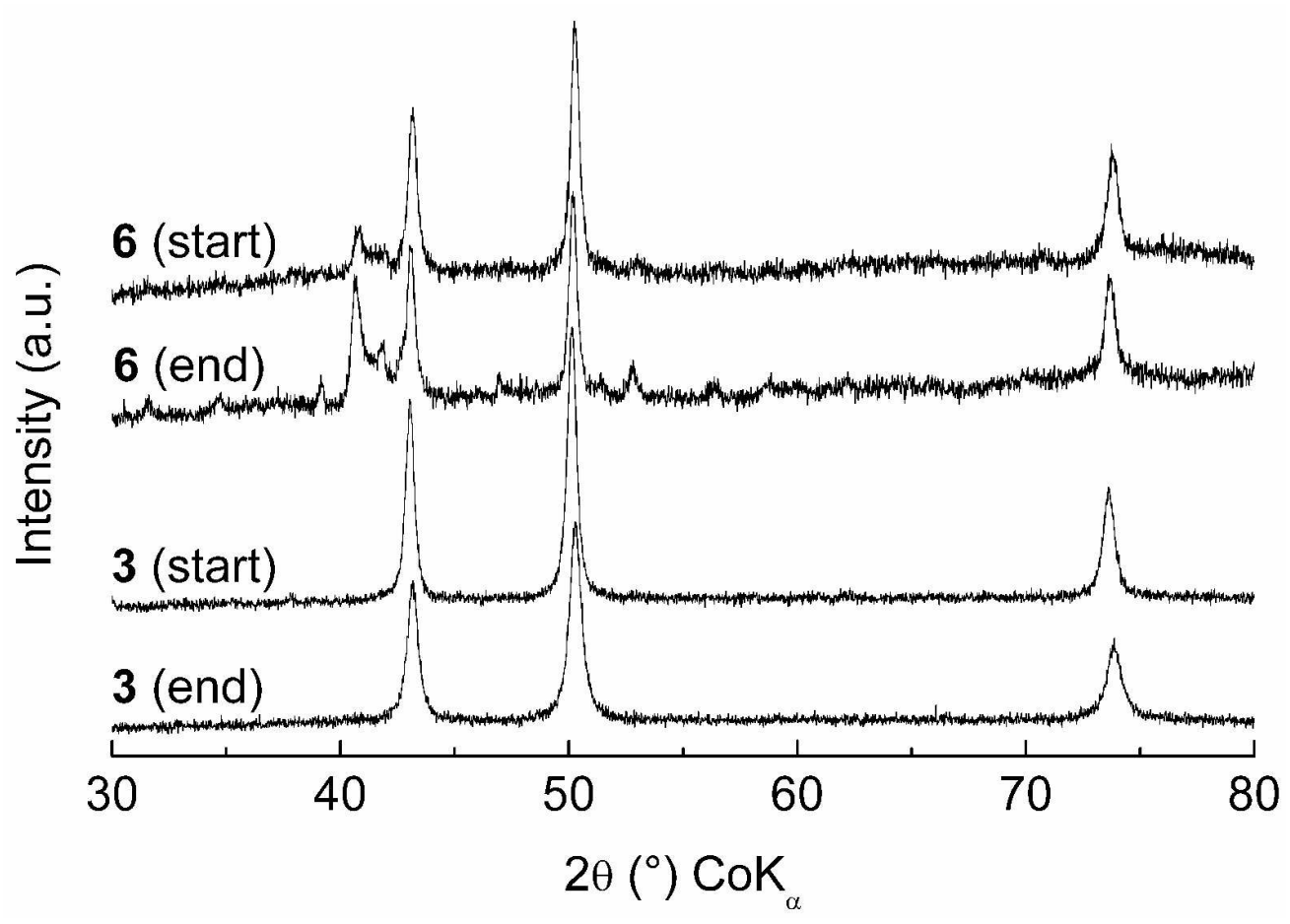

XRD patterns of the thermal decomposition products of the complexes 3 and 6 . The detected diffraction lines belong to $\mathrm{NiO}$ for 3 , and $\mathrm{NiO}, \mathrm{NiS}$ and $\mathrm{Ni3} 2 \mathrm{O} 6$ for 6 ; the start and end temperatures are given in Table 5. $269 \times 192 \mathrm{~mm}(600 \times 600 \mathrm{DPI})$ 
Schematic representation of the synthetic procedures applied for the preparation of the nickel(II) complexes 1-7; X = Cl- (1), Br- (2), I- (3) and NCS- (4), MY = LiClO4•3H2O (5), Na[BPh4] (6) and $\mathrm{K}[\mathrm{PF} 6](7)$. $109 \times 58 \mathrm{~mm}(600 \times 600 \mathrm{DPI})$ 

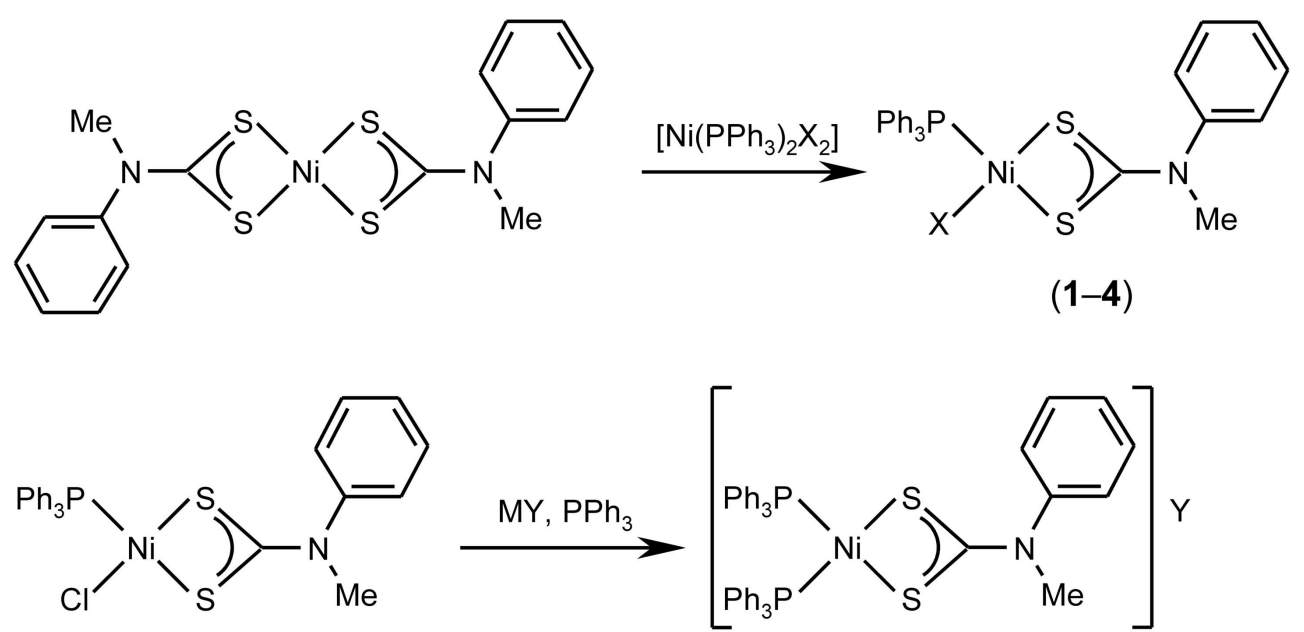

(1) (5-7)

$\mathrm{X}=\mathrm{Cl}^{-}$(complex 1), $\mathrm{Br}^{-}(2), \mathrm{I}^{-}(3), \mathrm{NCS}^{-}$(4) $\mathrm{Y}=\mathrm{ClO}_{4}^{-}(5), \mathrm{BPh}_{4}^{-}(6), \mathrm{PF}_{6}^{-}(7)$

Table of Contents Graphic $125 \times 76 \mathrm{~mm}(600 \times 600 \mathrm{DPI})$ 